\title{
An Early Caddoan Period Cremation from the Boxed Springs Mound Site (41UR30) in Upshur County, Texas, and a Report on Previous Archaeological Investigations
}

Timothy K. Perttula

Heritage Research Center, Stephen F. Austin State University

Diane E. Wilson

Mark Walters

Heritage Research Center, Stephen F. Austin State University

Follow this and additional works at: https://scholarworks.sfasu.edu/ita

Part of the American Material Culture Commons, Archaeological Anthropology Commons, Environmental Studies Commons, Other American Studies Commons, Other Arts and Humanities Commons, Other History of Art, Architecture, and Archaeology Commons, and the United States History Commons

Tell us how this article helped you.

This Article is brought to you for free and open access by the Center for Regional Heritage Research at SFA ScholarWorks. It has been accepted for inclusion in Index of Texas Archaeology: Open Access Gray Literature from the Lone Star State by an authorized editor of SFA ScholarWorks. For more information, please contact cdsscholarworks@sfasu.edu. 


\section{An Early Caddoan Period Cremation from the Boxed Springs Mound Site}

(41UR30) in Upshur County, Texas, and a Report on Previous Archaeological Investigations

Creative Commons License

(c) (i) (9)

This work is licensed under a Creative Commons Attribution-NonCommercial 4.0 International License 


\title{
AN EARLY CADDOAN PERIOD CREMATION FROM THE BOXED SPRINGS MOUND SITE (41UR30) IN UPSHUR COUNTY, TEXAS, AND A REPORT ON PREVIOUS ARCHAEOLOGICAL INVESTIGATIONS
}

\author{
Timothy K. Perttula and Diane E. Wilson, \\ with contributions by Mark Walters
}

\section{INTRODUCTION}

The Boxed Springs Mound site (41UR30) is one of three major Early Caddoan (ca. A.D. 900-1200) multiple mound centers in the Sabine River basin of northeastern Texas, the others including the Jamestown (41SM54) and Hudnall-Pirtle (41RK4) sites upstream and downstream, respectively, from Boxed Springs. It is situated on a large and prominent upland ridge projection that extends from a bluff on the Sabine River about $500 \mathrm{~m}$ north to where the landform merges with a broader stretch of uplands and Bienville alluvium (Figure 1). Sediments on the site are Trep loamy fine sand, a relatively fertile soil (see Roberts 1983). The site is approximately $1.6 \mathrm{~km}$ west of the confluence of Big Sandy Creek and the Sabine River, but the old channels, sloughs, and oxbow lakes on both sides of the upland ridge and alluvial terrace suggest that previous channels of the Sabine River as well as Big Sandy Creek ran from north to south immediately adjacent to the site.

When the Boxed Springs site was originally recorded by Sam Whiteside, an avocational archeologist from Tyler (see Walters and Haskins, this volume) in the early 1960s, it had four earthen mounds arranged around an open area or central plaza (Figure 2). The four mounds apparently included two low "structural" or house mounds with clay floors at the southeastern and southwestern ends of the plaza (Mounds \#2 and \#7 on a ca. 1962 sketch by Whiteside), one burial mound about $12 \times 8 \mathrm{~m}$ in size and $1 \mathrm{~m}$ in height at the northwestern plaza edge (Mound \#3), and a flat-topped mound of unknown function at the northeastern end of the plaza (Mound \#6). There were borrow pits apparently visible to the east of Mound \#3 and south of Mound \#6 (although not shown on the ca. 1962 sketch map), and occupation areas/midden deposits (\#1 and \#8) along the uplands at the southem edge of the site as well as north and northwest of Mound \#3 (areas \#4 and \#5 on Figure 2).

Some years ago (about 1990), while Dr. James E. Bruseth and Dr. Timothy K. Pertula were documenting a large collection of vessels and stone tools from the Boxed Springs site (see discussion below), they became aware of the fact that a cremation burial with associated vessels had been dug at the site. A few years later, the cremated remains from that burial were turned over to Dr. Perttula for study. In this paper, Diane E. Wilson summarizes for the first time the results of her bioarchaeological analyses of the cremated burial. With this information now available, it seemed appropriate to provide an archaeological context--as it was known--on the cremated burial, and also summarize in one place the available information on the archaeological record from the Boxed Springs site. Key to this effort was the fact that Mark Walters provided unpublished information and notes from the 1960s archaeological investigations by Sam Whiteside at the Boxed Springs site.

Although it is a major Early Caddoan mound center, the archaeology of the Boxed Springs site is very poorly known. We hope that this paper on a cremated burial from the site, as well as a discussion of previous archaeological investigations at Boxed Springs, will rectify 


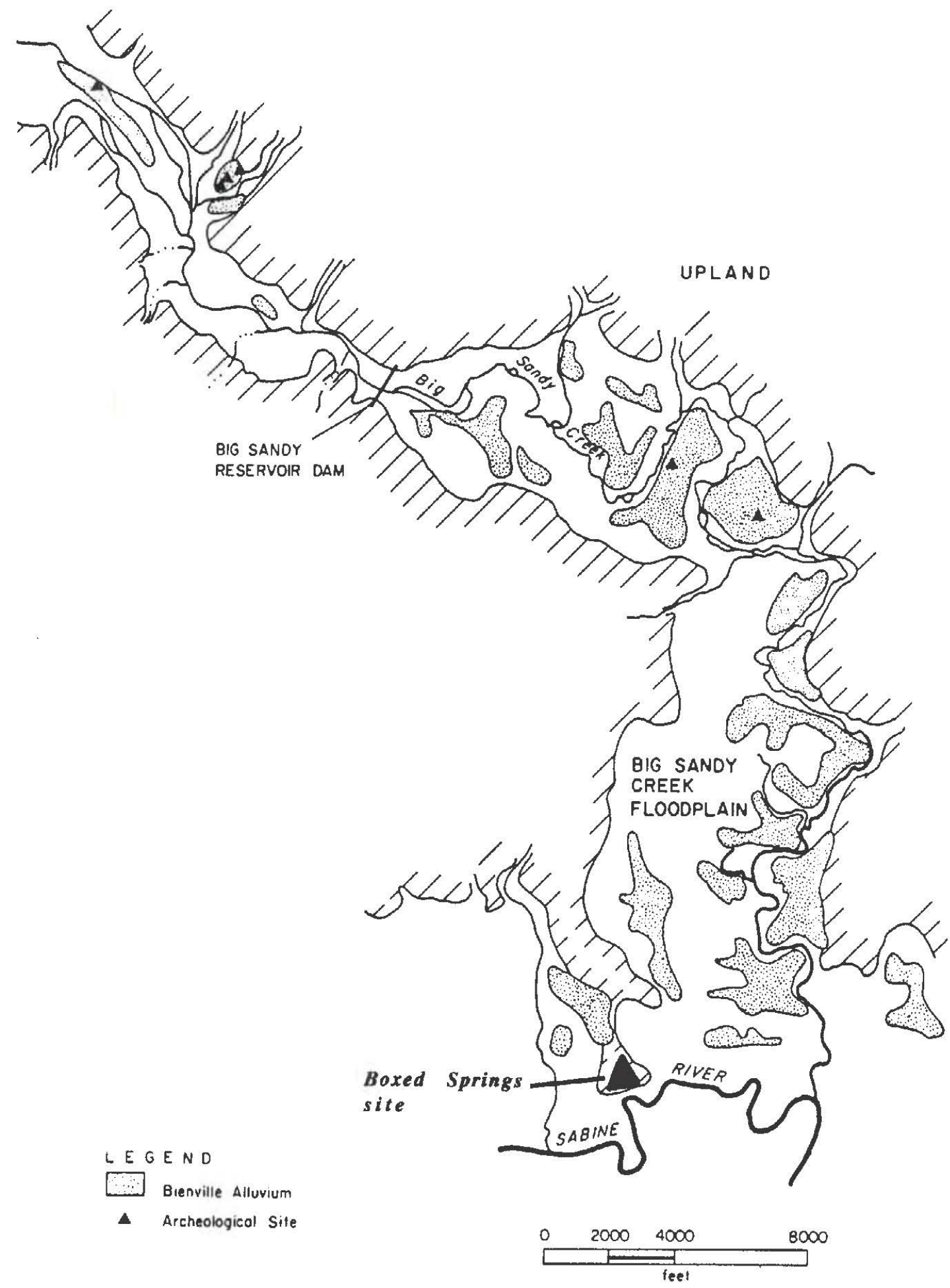

Figure 1. General location of the Boxed Springs site along the Sabine River. 

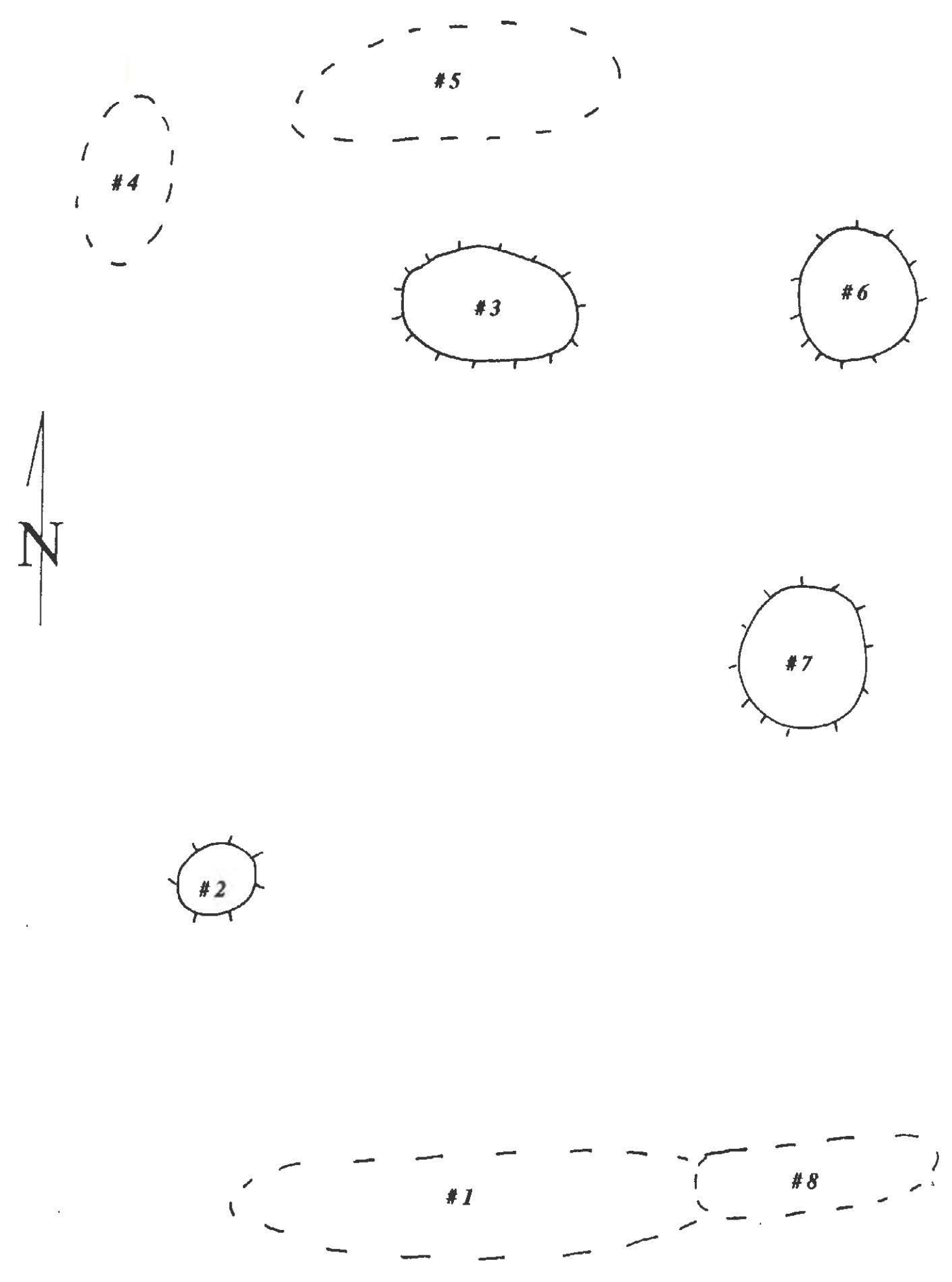

Figure 2. Sam Whiteside map, ca. 1962, \#2, \#3, \#6, and \#7 are mounds, and \#1, \#4, \#5, and \#8 are occupation areas. 
this situation to a certain extent, and also spur renewed professional archaeological interest in this very significant prehistoric Caddoan mound center.

\section{THE CREMATED REMAINS FROM THE BOXED SPRINGS SITE (41UR30), by Diane E. Wilson}

The analysis of human remains from the Boxed Springs site (41UR30) was limited to an isolated cremated burial in a large cemetery at the northern end of the site. Ceramic vessels believed to be associated with the burial (see Perttula, below) suggest a date of ca. A.D. 900-1100 for the cremation. Although fairly common during the Woodland period (see discussion in Perttula 1999:387), cremated burials are occasional occurrences at Caddoan sites, with the predominant form of burial being single extended and supine burials. During Early Caddoan times, however, cremation was apparently more common than in later times.

In the analysis of cremations, data collection is limited by preservation conditions, but they do provide valuable information on mortuary practices. The osteological examination reported here was conducted using standard techniques as outlined in the Texas A\&M University, Physical Anthropology Laboratory Data Form for human remains, and those techniques presented in Buikstra and Ubelaker (1994). Observations were made by hand with the aid of a $10 \mathrm{X}$ hand lens.

The burned remains include isolated but relatively complete skeletal elements, but the majority were highly fragmented materials. When possible, bone identification and sex and age information were recorded for that element. Isolated elements and larger fragments were also identified and inventoried. In addition, the degree and pattern of burning was recorded during the analysis.

From these remains it was determined that the cremation was that of a single individual. This individual was probably an adult male whose body was burned at a low temperature while the bones were articulated and in the flesh.

Most of the burned remains were reduced to splinters and extremely small fragments of bone. The total weight of the cremation was 335.2 grams. The largest fragment was a nearly complete right talus, which measured approximately $55 \mathrm{~mm}$ in length. This suggests that the individual was male (Steele 1976), although it should be cautioned that the talus was incomplete and had been burned and was visibly cracked longitudinally and transversely. Other identified fragments were: a left mandible fragment, a right patella fragment, four rib fragments, one vertebral neural arch fragment, three phalanx fragments of the feet, two metatarsal fragments, one fibula fragment, 28 long bone fragments, and four cancellous bone fragments. No teeth were present. The size and epiphyseal surfaces present suggest that the individual was an adult.

None of the bone had a blue-gray calcined appearance. Instead, the bone was a pale tan color on the exterior surface with a black, charcoal-like appearance on the inner surfaces. This color pattern indicates that the individual was burned at a very low temperature, likely as low as 200 degrees Centigrade (Buikstra and Ubelaker 1994). The light tan color of the exterior surface of the bones also suggests that the bones were covered by flesh at the time of burning. Differential burning is evident, with little burning on the larger fragments, whereas most long bone fragments are more heavily charred. This again is typical of burning with flesh present of a primary articulated individual, rather than after disarticulating. 
Larger bones are predominantly cracked in a transverse plane, which is consistent with burning when the bone is green or covered with flesh. Cracking on bone surfaces was extensive. Very little warping was observed on the fragments, but most fragments were too small to observe this feature. Rootlets were present with the remains, but there was no evidence of root etching. No other biological alteration was observed on the larger fragments, and there was no evidence of pathological conditions, disarticulation, cut marks, or depressed fractures. It was not possible to take metric or non-metric observations.

\section{ARCHAEOLOGICAL CONTEXT OF THE CREMATION, by Timothy $K$. Perttula}

Little specific information is available on the archaeological context of the cremation reported on by Diane E. Wilson. It is known that the cremation was a single burial feature dug in a large cemetery at the northern end of the site (north of a large metal farm building north of areas \#4 and \#5 on Figure 2); there is no evidence available that suggests that the cremated individual was burned in place; rather, it appears that the individual was cremated elsewhere (on the site?), and the burned remains were gathered up for burial, along with two (or three?) complete ceramic vessels placed in the burial pit as funerary objects with the cremation. Vessels apparently found with the cremation included a Spiro Engraved bowl and an East Incised bowl, along with a Red River style long-stemmed pipe.

\section{PREVIOUS INVESTIGATIONS AT THE BOXED SPRINGS SITE, $b y$ Timothy $K$. Perttula and Mark Walters}

The Boxed Springs site was originally identified by a Mr. Norman Bedgood of Tyler, Texas, while he was flying his airplane along the Sabine River. He was a member of the East Texas Archeological Society (ETAS), and he informed Sam Whiteside, a fellow ETAS member, who undertook archaeological investigations in 1962. At the time, the site was owned by the Ledsinger family, from Kilgore, Texas, who maintained a fishing camp on the property.

\section{Whiteside Investigations}

In 1962, Sam Whiteside excavated in two mounds at the Boxed Springs site, and collected a limited amount of Caddoan artifacts from the surface in the vicinity of several of the mounds. In his 1962 notes, he referred to the mounds by numbers (i.e., \#2, \#3, \#6, and $\# 7$ ), and his excavations took place in mounds \#3 and \#7. To be consistent with subsequent archaeological investigations at the Boxed Springs site by Dr. Dee Ann Story and the University of North Texas (see below), and with the provenience information on the collections housed at the Texas Archeological Research Laboratory, The University of Texas at Austin (TARL), hereafter the mounds will be referred to by letters, as follows: Mound A (\#3), Mound B (\#6), Mound C (\#2), and Mound D (\#7). A ca. 1982 sketch map by Sam Whiteside indicates the four mounds, associated borrow pits east of Mound A and south of Mound B (Figure 3), a midden area north of Mound B, and an occupation area between Mounds $\mathrm{C}$ and $\mathrm{D}$.

According to Whiteside's notes on Mound A excavations, he removed the mound fill with a farm tractor and a 5 foot metal blade, then used a shovel and trowel to search for features. The mound fill was a homogeneous gray sandy loam. Other than a rectangular patch of brown clay just below the mound surface in the south-central part of the mound (Figures 4 and 5), no features were located in the mound fill until a depth of 3.5 feet below the top of 

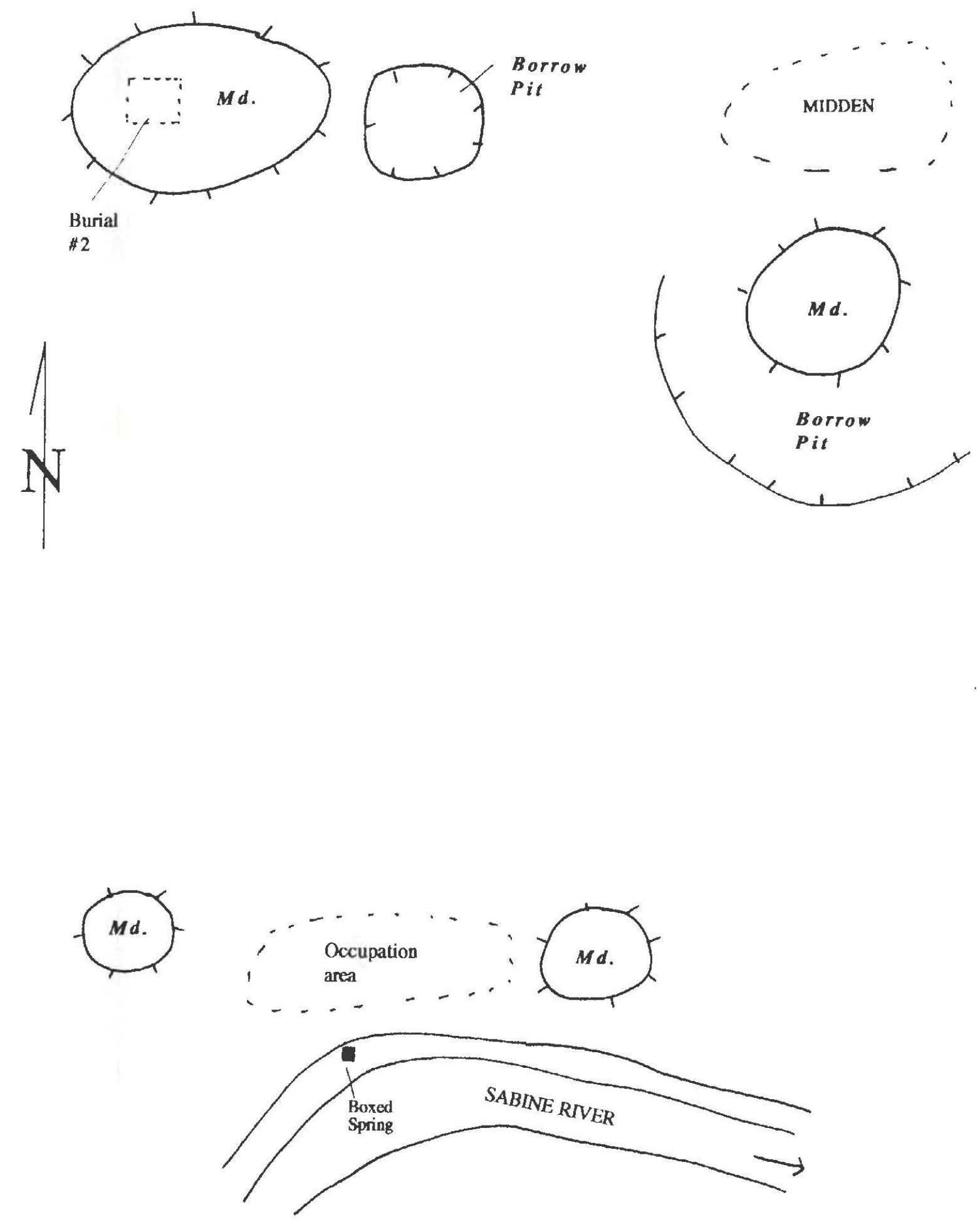

Figure 3. Sam Whiteside map, ca. 1982. 


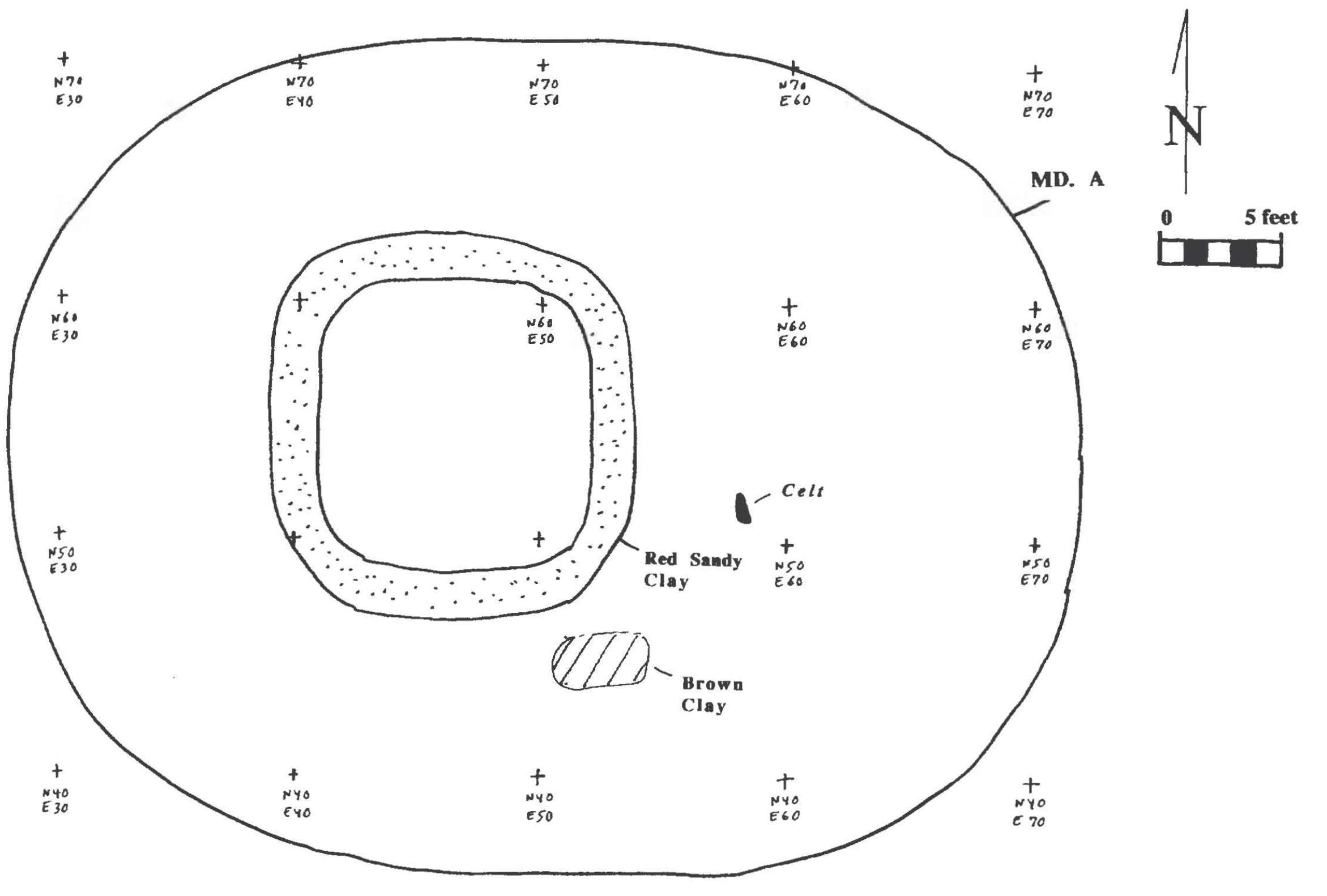

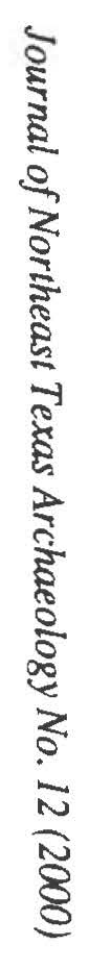

Figure 4. Mound A excavations, and location of Burial 2 pit. 


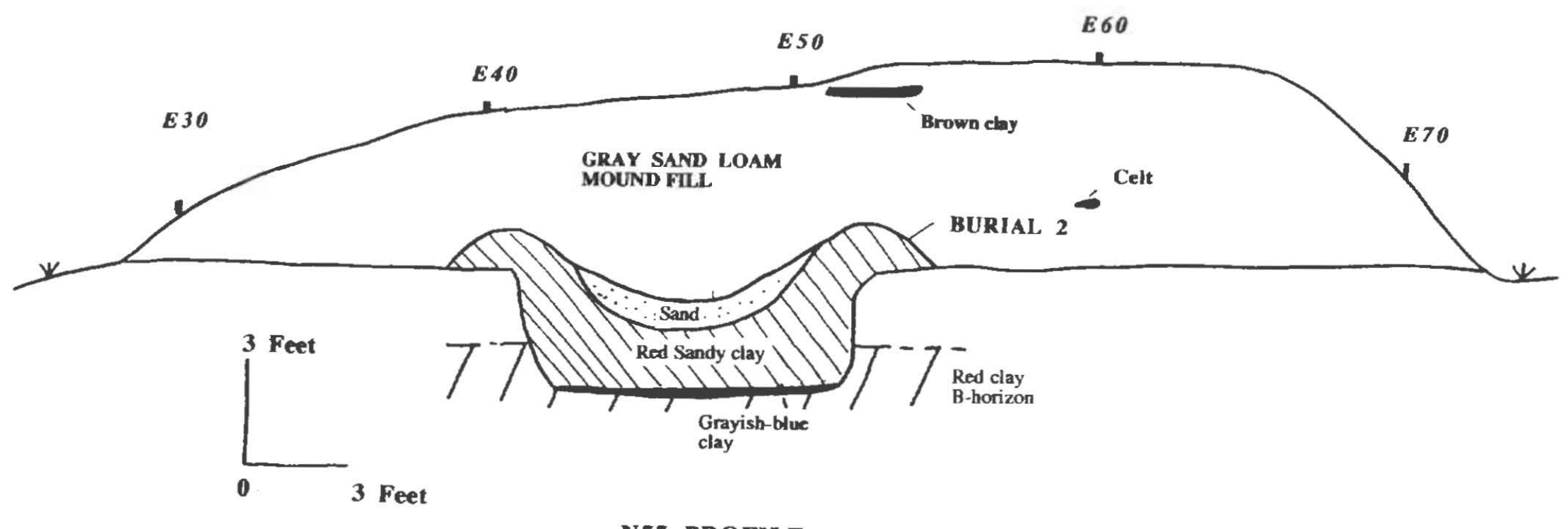

N55 PROFILE

Figure 5. N55 profile in Mound A, showing Burial 2 pit, celt from Burial 1, and brown clay. 
the mound. This particular feature consisted of a charcoal stain and fragments of human bone (Burial 1), some of which were charred, as well as a human molar, all in the eastem part of the mound (see Figures 4 and 5). While this burial feature was being troweled, a large greenstone celt was recovered (Figure 6), along with more human bone and a mano (the exact location of the mano is not known, but Figures 4 and 5 show the horizontal and vertical location of the large celt). The human remains were poorly preserved in Burial 1 , and the soil around the bone and artifacts showed no evidence of a burial pit, suggesting the burial may have been placed on the mound as it was being built.

The top of the mound had apparently been previously disturbed by pothunters, as there were numerous looter holes in it, and the human remains in Burial 1 appeared to have been disarranged. One piece of baling wire was found near Burial 1, and this was probably discarded by the pothunters.

Whiteside's notes indicate that few artifacts were present in the mound fill, other than pieces of lithic debris. The absence of sherds in the mound fill suggests that this part of the Boxed Springs site (including the borrow pit area just east of Mound A, see Figure 3) had not been previously occupied by Early Caddoan groups before the construction of Mound A.

Continued excavations in Mound A indicated that the mound was a maximum of 6 feet $(1.83 \mathrm{~m})$ in height and $35 \times 43$ feet $(10.7 \times 13.1 \mathrm{~m})$ in length and width (see Figure 4). With the removal of all the mound fill with the tractor blade, a large circular ring of clay was exposed near the base of the mound (see Figures 4 and 5). This ring of red sandy clay was $0.6 \mathrm{~m}$ in width and $16 \mathrm{~cm}$ thick, and marked a berm around a large clay- and sandfilled pit that extended approximately $0.9-1.2 \mathrm{~m}$ below the original ground surface under the mound; the top of the berm was between 0.6-1.2 m below the top of the mound (Figure 7).

Excavations of the pit proceeded with shovel and trowel to about $30-40 \mathrm{~cm}$ above the pit floor, and the remainder of the pit was carefully troweled until the pit floor was reached. The pit was $12.5 \times 13.5$ feet at the top $(3.8 \times 4.1 \mathrm{~m})$, and narrowed to $10.5 \times 11.5$ feet $(3.2 \times 3.5 \mathrm{~m})$ at the bottom (see Figure 7), and had rounded corners and slightly sloping walls. The upper and central portion of the pit had a white sand fill, with the remainder of the fill and berm grading from a sandy red clay to a very dense red clay just above the floor. The pit floor was covered with a $2.5-5 \mathrm{~cm}$ thick lens of bluish-gray clay, probably obtained from Pleistocene alluvial deposits along the Sabine River.

Early Caddoan burials in mounds at the George C. Davis (F134 in Mound C, Story 1997) and Mounds Plantation sites (Burial Pit 5, Mound 5, Webb and McKinney 1975) also had clay berms around the centrally-placed burial pits, and they also contained multiple individuals. The burial pits were much larger at these two sites than Burial 2 at Boxed Springs: 7 x $5.5 \mathrm{~m}$ at George C. Davis (Story 1997:18) and $5.8 \times 5.2 \mathrm{~m}$ at Mounds Plantation (Webb and McKinney 1975:54). At both these sites, the burial pits were covered with a $\log$ tomb; no direct evidence for a log tomb was recovered from Burial 2 at Boxed Springs, but the depressed lens of white sand in the center of the pit (see Figure 7) suggests that the pit feature may have been left open for a time, or covered with a wood frame, and the sand may have washed into the top of the pit.

At George C. Davis, F134 had eight extended adult burials, but they were oriented northsouth, with their heads facing south (Story 1997:Figure 12). There were extensive burial offerings (Story 1997:21-23). The Mounds Plantation burials in Burial Pit 5 were placed in five groups of extended burials (totaling 21 individuals, including three fetuses), with four groups oriented east-west, with the head facing east (Webb and McKinney 1975:Figure 5). 


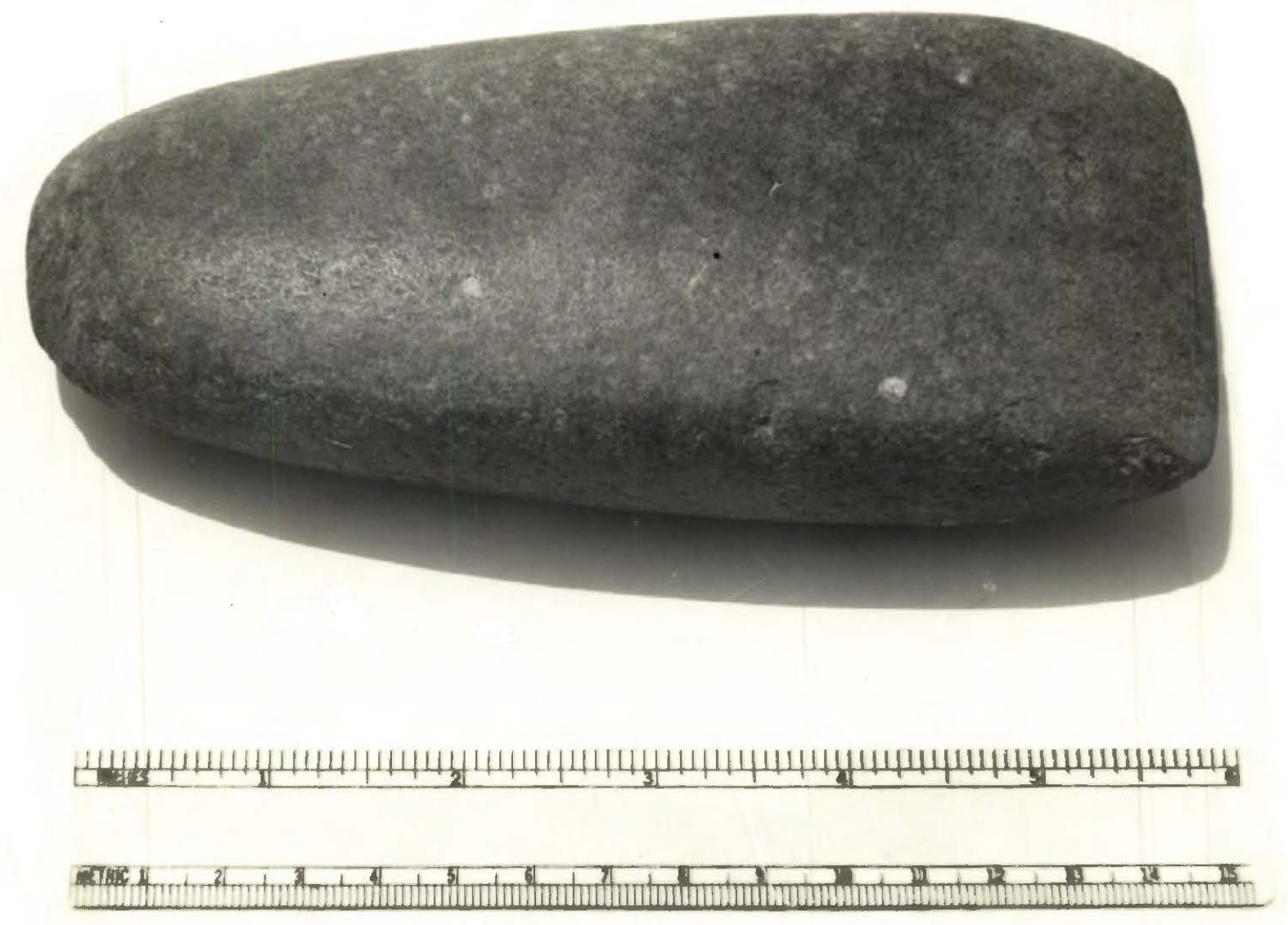

Figure 6. Celt associated with Burial 1, Mound A. 


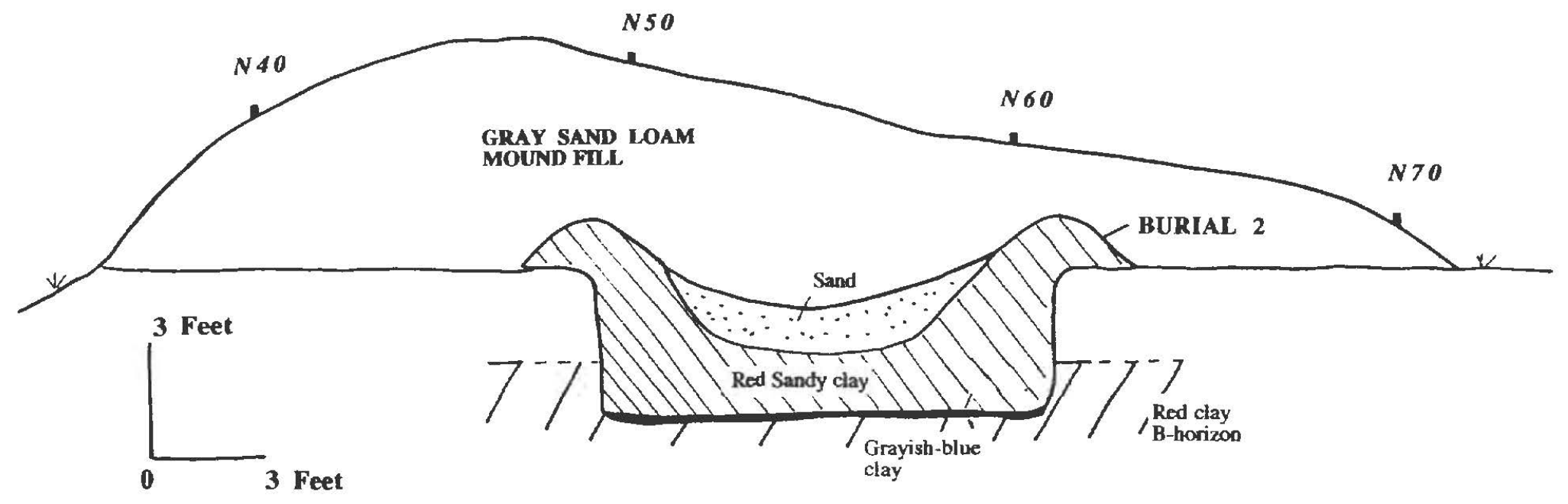

E45 PROFILE 
A wide variety of funerary offerings were placed in Burial Pit 5 at Mounds Plantation, including ceramic vessels, ceramic pipes, arrow points, chipped stone knives, wood artifacts, cane matting, stone beads and pendants, as well as other items.

The pit feature at Boxed Springs, Burial 2, contained three sets of teeth enamel along the eastern side of the pit; no other human remains were preserved in the feature (Figure 8). The broad spacing of the sets of teeth enamel suggest that Burial 2 contained the bodies of three individuals that were laid out east-west, with the head facing west. Most of the artifacts placed on the floor of the burial pit were along the north side of the feature, north of the third set of teeth enamel, although three of the clusters of arrow points were in the central and southern part of the feature, and one ceramic vessel (Vessel 5, a plain bottle) was near the eastern pit wall (see Figure 8). Funerary objects placed in Burial 2 included two large chipped stone bifaces, five groundstone celts, several polished stones, a ferruginous sandstone tool, four clusters of arrow points, and seven ceramic vessels (V. 1 through V. 7, see Figure 8).

The large and well-made chipped stone bifaces were found together on the northern side of the pit, and immediately north of the five groundstone celts (see Figure 8). Both appear to have been made from non-local cherts--probably from Central Texas--and one may have been heat-treated based on its lustrous appearance (Figure 9). The larger biface (about 16 $\mathrm{cm}$ in length) is a Gahagan Biface (Shafer 1973:224 and Figure 19), while the other compares well with the Group 2 bifaces at the George C. Davis site (Shafer 1973:Figure 19w).

The ferruginous sandstone tool is a tabular piece about $20 \mathrm{~cm}$ in length and $4 \mathrm{~cm}$ in width (Figure 10), with straight and smoothed edges. The Boxed Springs tool resembles tabular sandstone saws recovered in Early Caddoan contexts at the George C. Davis site (Shafer 1973:317 and Figure 25h-i). It was placed between Vessels 3 and 4, and near a polished pebble (see Figure 8).

The two polished stones are pebble-sized pieces of chert about 3-4 cm in length and width (Figure 11). They may have been used to polish ceramic vessels after they had been successfully fired. One of the polished stones was near the ferruginous sandstone tabular tool, and the other was amidst arrow point cluster \#1 in the northern part of the burial pit (see Figure 8). The mano included in Figure 11 was apparently found in close association with Burial 1 (see above).

The five celts in Burial 2 were found cached together near the northernmost set of teeth enamel, and immediately south of the two large chipped bifaces and Vessel 1, a plain bottle (see Figure 8). The celts are small in size, ranging from $5-10 \mathrm{~cm}$ in length, and are relatively narrow compared to the width of the bifacially beveled bit and poll (Figure 12). On one angular celt, the bit width is only $13 \mathrm{~mm}$ (see Figure 12, second from left), while the bit width on the other four specimens ranges between ca. $26-32 \mathrm{~mm}$. The celts were made from non-local raw materials, probably of metamorphic or igneous origin and originating in the Ouachita Mountains of southeastern Oklahoma and southwestern Arkansas, and at least one may be diorite or Hatton tuff (see Figure 12, far left).

As previously mentioned, there were four clusters of arrow points in Burial 2. Cluster \#1, at the northern end of the pit (see Figure 8), had 55 specimens. They apparently were not on shafts or in a quiver when they were placed in the burial pit, because they were turned in various directions. Whiteside's notes comment that the cluster \#1 points were found lying on a ferruginous sandstone rock (presumably the tabular ferruginous sandstone piece described above), but his plan map of Burial 2 (see Figure 8) indicate that the tabular ferruginous sandstone piece was about 0.60 m east of cluster \#1. 


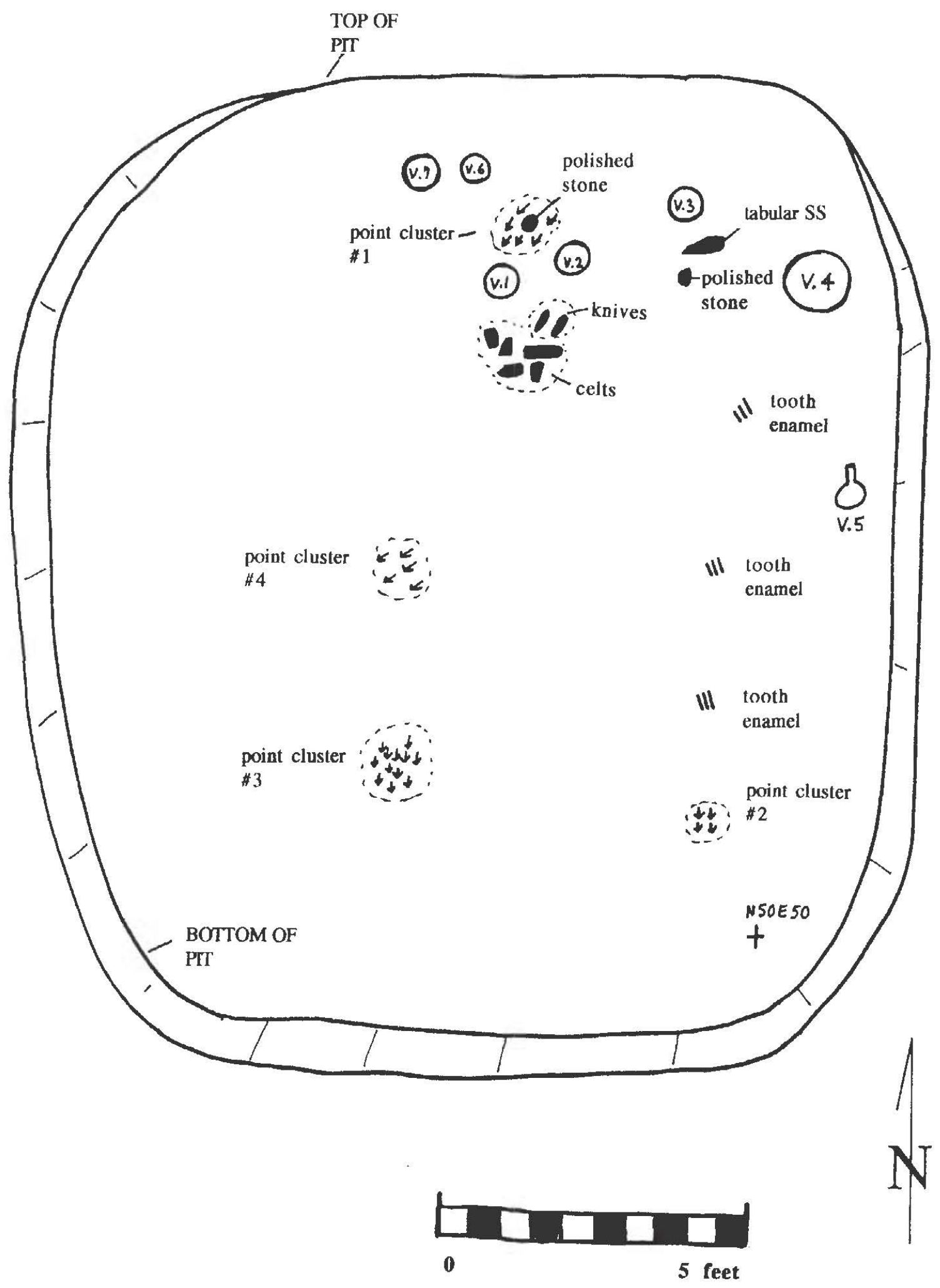

Figure 8 . Burial 2 pit and location of funerary objects. V.1-V.7 are 7 pottery vessels. 


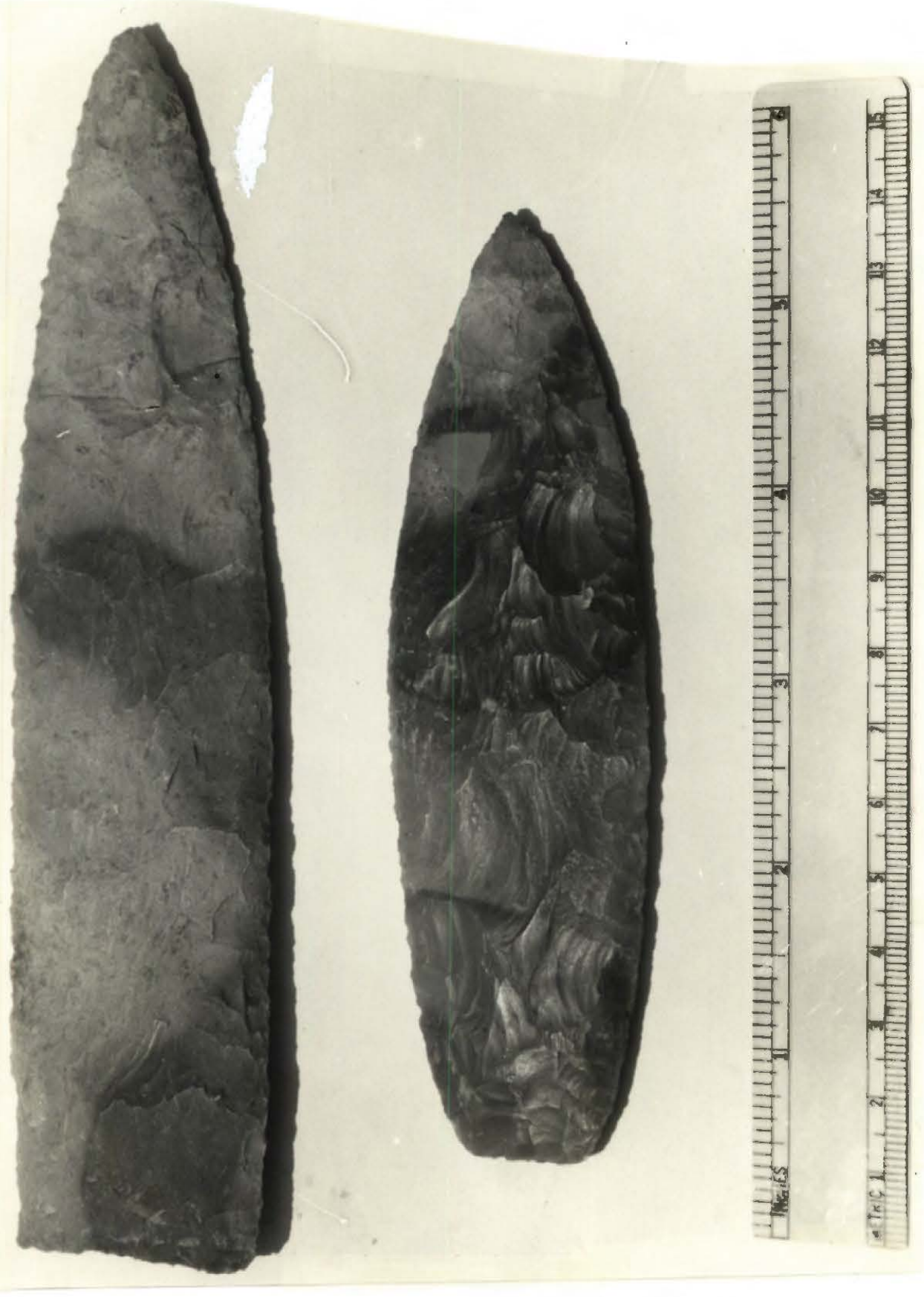

Figure 9. Large bifaces in Burial 2 pit. 


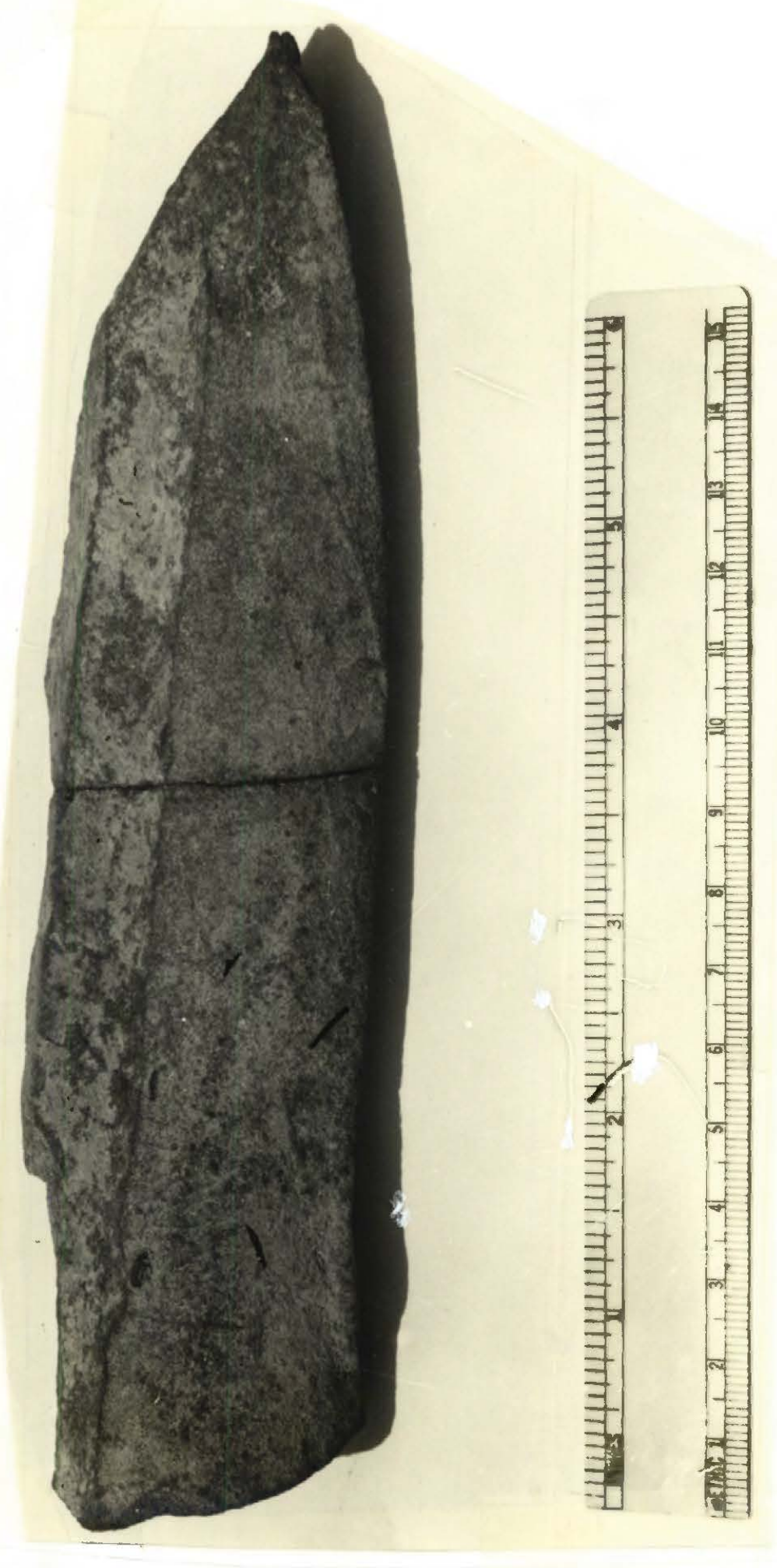

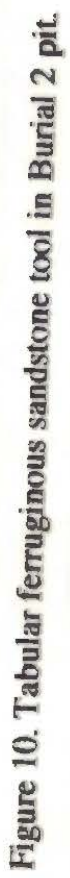




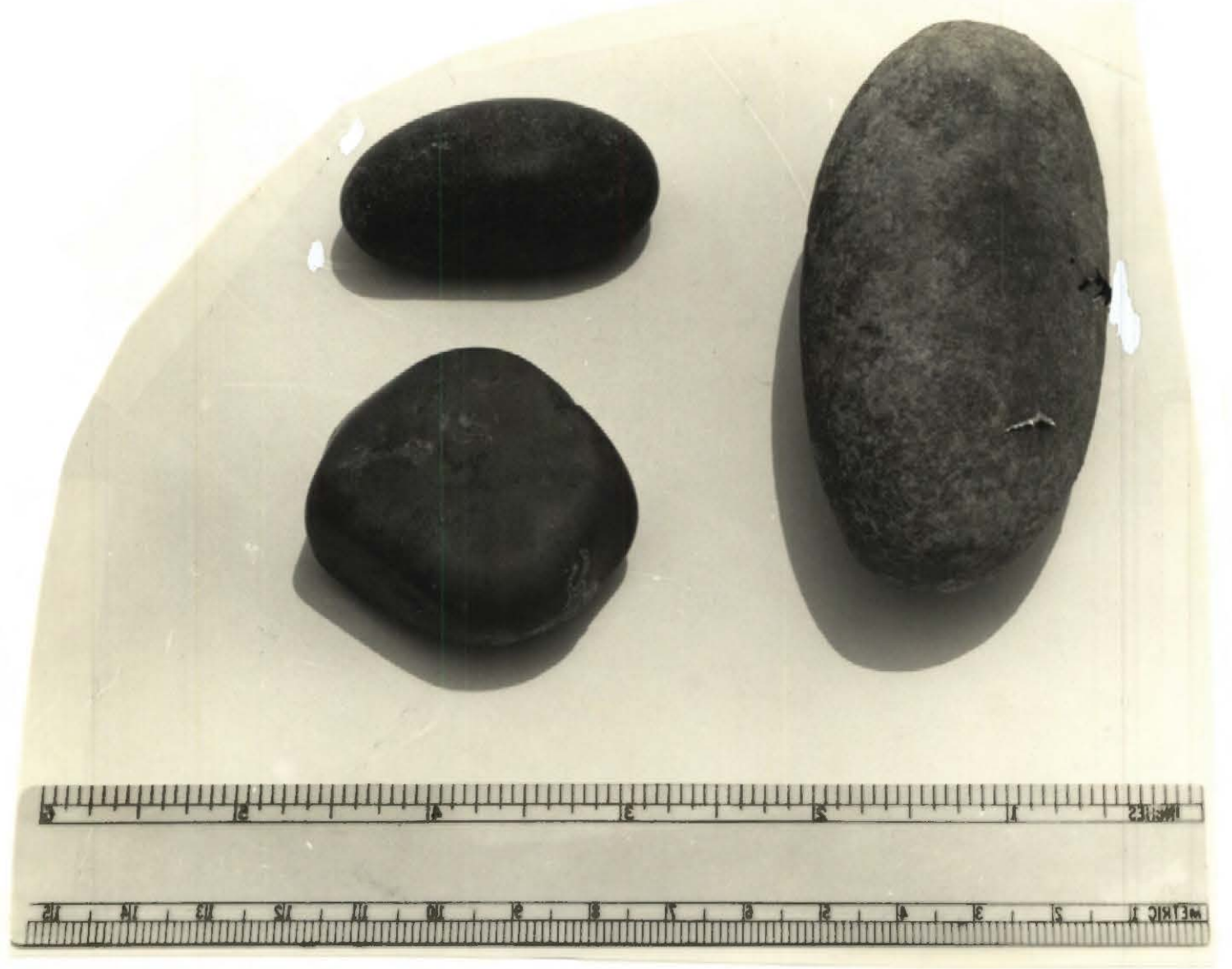

Figure 11. Polished stones from Burial 2 and mano from Burial 1. 


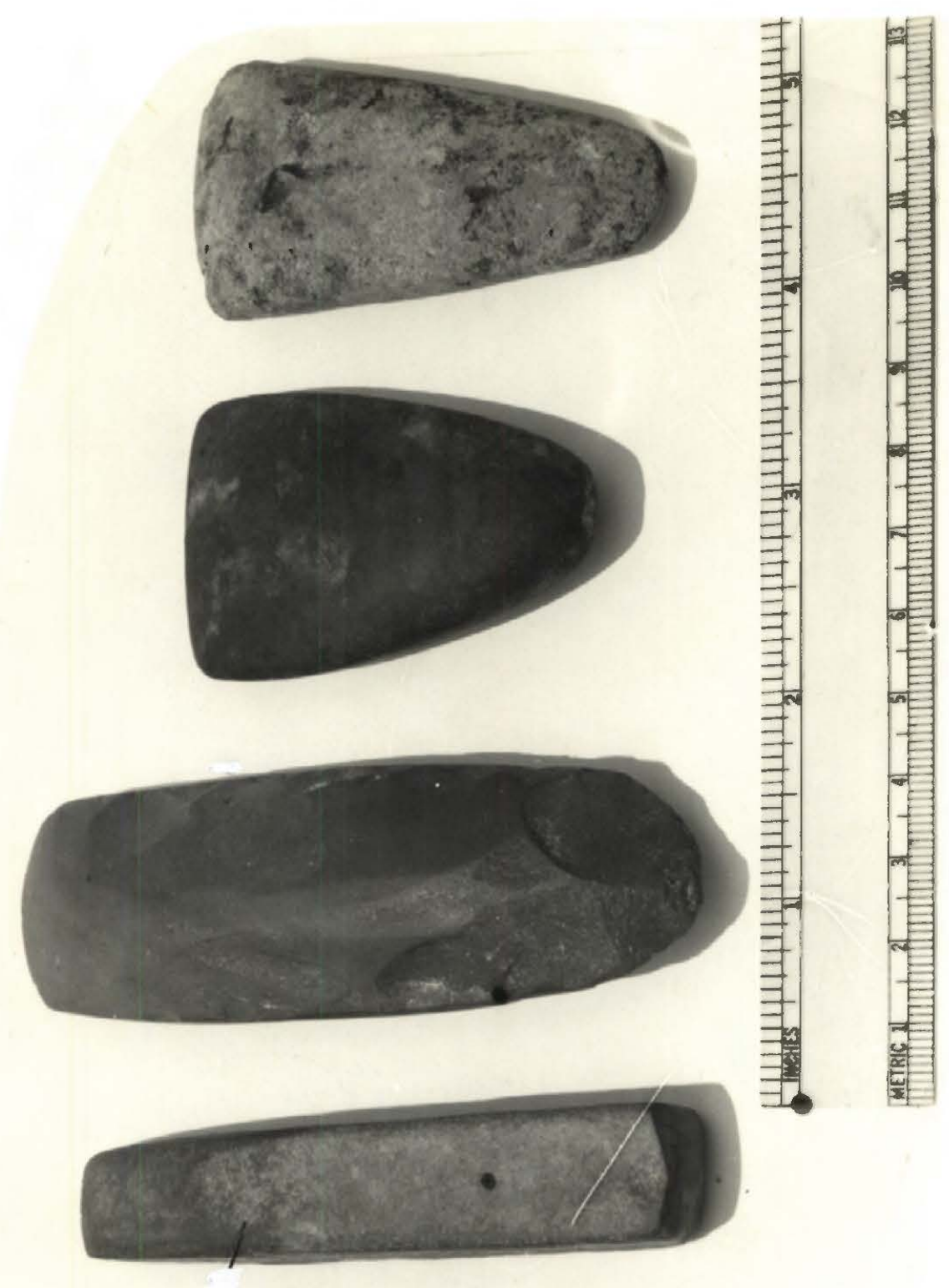

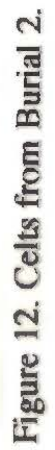


Arrow point cluster \#2 had four specimens, while cluster \#3 had 36 points and cluster \#4 had five arrow points. All the cluster \#3 points were pointing south and probably were shafted and in a quiver. The direction of the cluster \#2 and \#4 arrow points was not determined. These three arrow point clusters were placed in the central and southern parts of the pit, in apparent association with the central and southern sets of tooth enamel (see Figure 8).

Stylistically, the arrow points from Burial 2 at Boxed Springs are rather morphologically homogeneous (Figures 13-16). Most have square or parallel stems with squared barbs and flat bases, or have square/parallel stems with concave bases (Alba Several of the square stemmed points have more sweeping barbs, similar to the Catahoula type, and there are a few specimens with a diamond-shaped stem comparable to the Hayes type. A variety of raw materials were used in the manufacture of the Boxed Springs arrow points, including fine-grained and coarse-grained quartzite, local cherts of brown and yellow hue, and high quality cherts that probably originated in the Ouachita Mountains and/or Red River gravels (see Banks 1990).

The seven ceramic vessels in Burial 2 cluster in the northern end of the pit (see Figure 8). Vessel 1 is a plain bottle, and Vessel 2 is a small (ca. $10 \mathrm{~cm}$ in height) Spiro Engraved beaker (Figure 17). These vessels were placed between arrow point cluster \#1, the two large chipped bifaces, and the five celts. Vessel 3 is a $13 \mathrm{~cm}$ tall everted rim jar with a pinched body and a zoned incised-cane punctated decoration on the rim (Figure 18). It was placed immediately north of the tabular ferruginous sandstone tool and $0.60 \mathrm{~m}$ east of arrow point cluster \#1 (see Figure 8).

Vessels 4 and 5 lay along the eastern side of the burial pit, between the pit wall and the central and northernmost sets of tooth enamel (see Figure 8). Vessel 4 is a large plain carinated bowl, and Vessel 5 is a plain bottle with a straight neck and a globular-shaped body (Figure 19). The bottle stands ca. $23 \mathrm{~cm}$ tall.

Vessels 6 and 7 were placed next to each other at the northern end of the Burial 2 pit, between 15-30 cm north-northwest of arrow point cluster \#1 (see Figure 8). Both are plain jars.

Not much information is available on the other three mounds at Boxed Springs. Whiteside's notes described Mound B as a "sand fill md.," but what it covered was not ascertained. There apparently was a borrow pit area immediately to the south of this mound (see Figure 3). Mound C was $35 \times 44$ feet in dimensions $(10.7 \times 13.4 \mathrm{~m})$, and apparently covered a house with a prepared clay floor. A $2 \times 12$ foot trench had been dug by pothunters into the center of the mound sometime prior to 1962 , but what was discovered is not known. Finally, Mound D also apparently covered a house with a prepared clay floor, and the mound fill was a $45 \mathrm{~cm}$ thick zone of sand.

Most of the artifacts collected by Whiteside at the Boxed Springs site have been donated to TARL. These include all the funerary objects recovered from Burial 2 in Mound A, as well as a few plain and decorated sherds from north of Mound A (Figure 20), near Mound D (Figure 21), and from unspecified contexts (Figure 22). Many of the decorated sherds have multiple horizontal incised lines, and several have impressed triangles below the horizontal incised lines (see Figure 21, cf. Coles Creek Incised, var. Coles Creek). Punctated and pinched rim and body sherds are also present, along with a large cross-hatched incised and punctated sherd from general contexts (see Figure 22, upper left) and a Holly Fine Engraved rim sherd (see Figure 22, second from left on bottom row). 


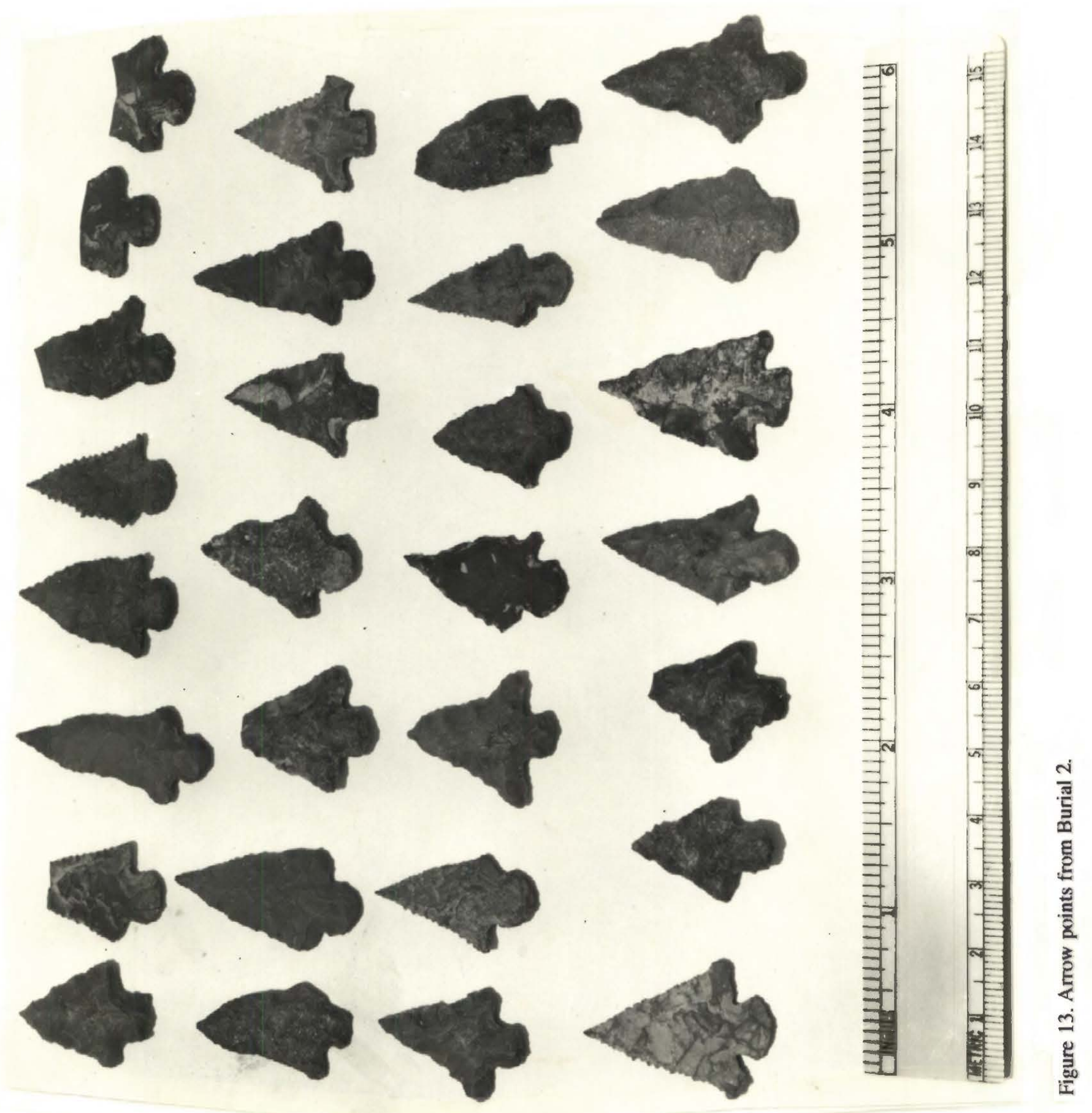




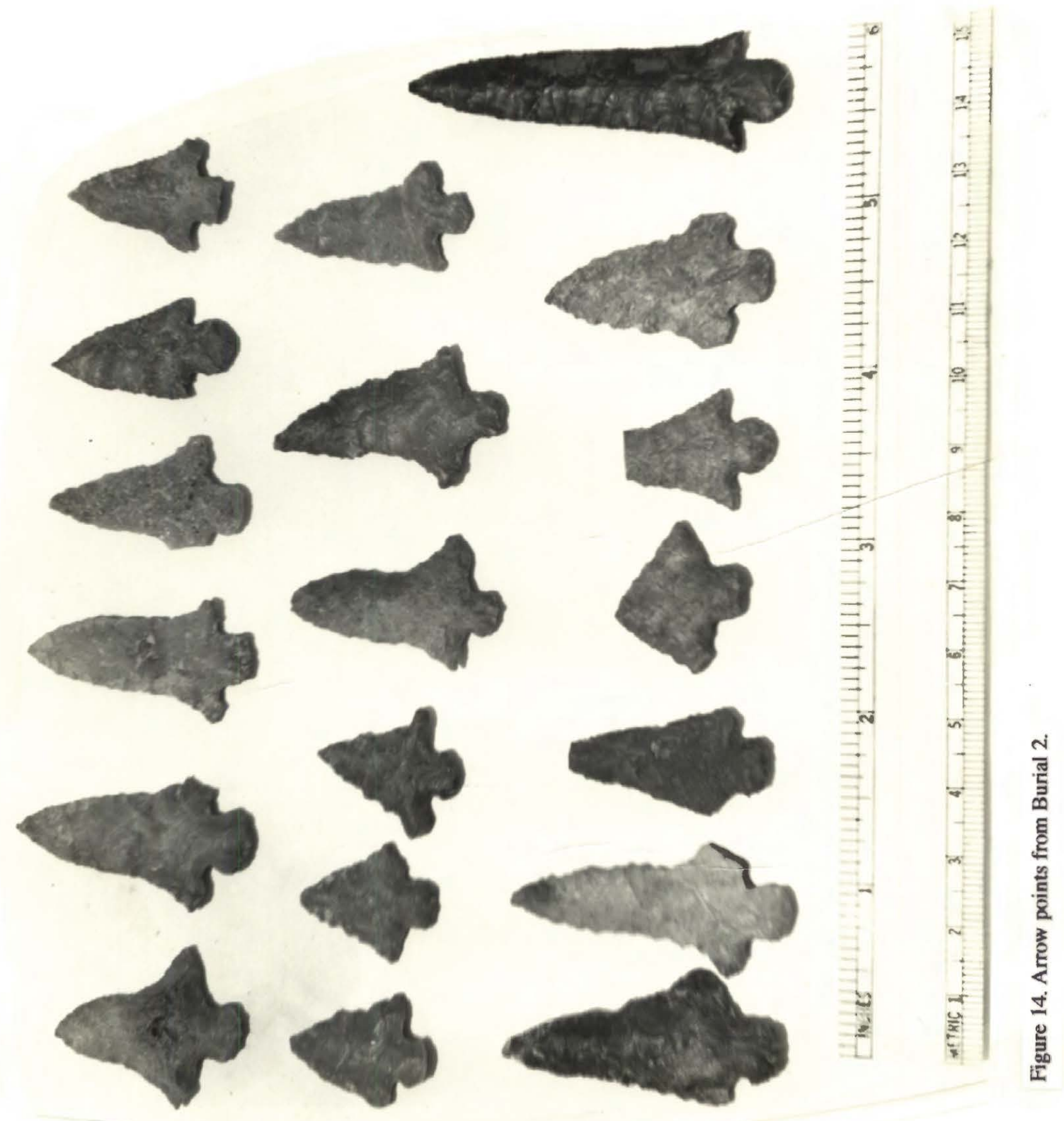




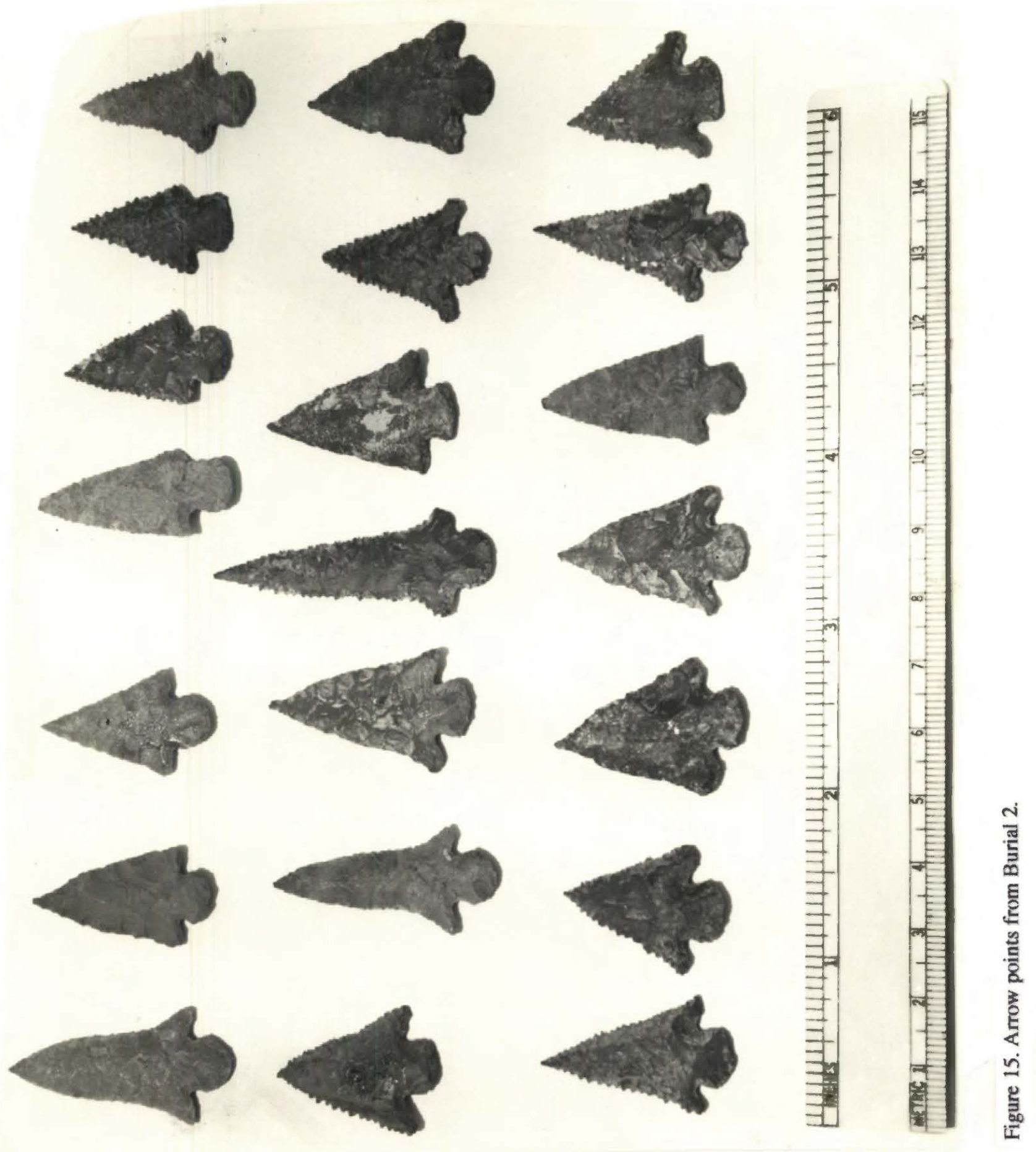




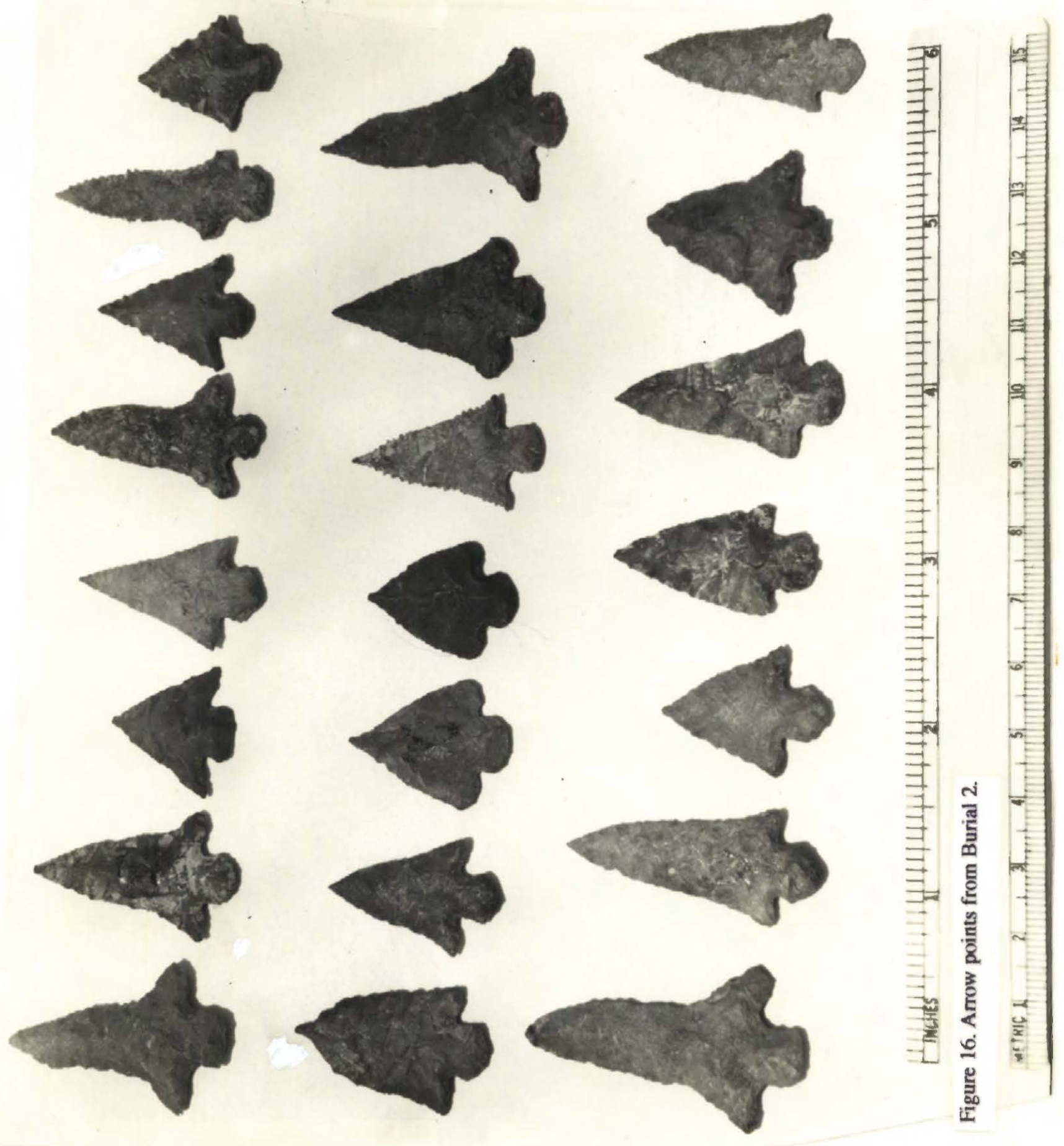




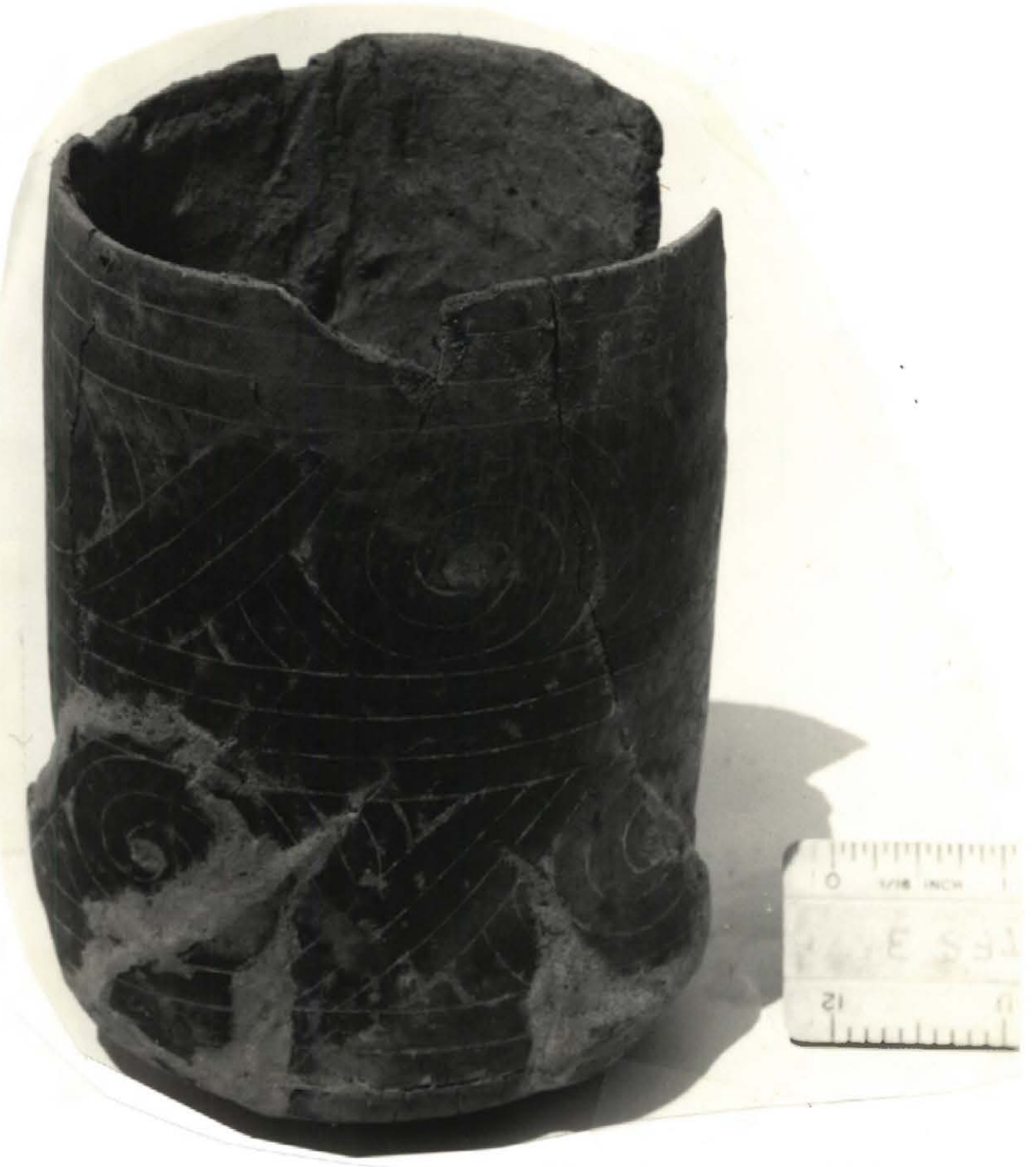

Figure 17. Spiro Engraved beaker from Burial 2 (Vessel 2). 


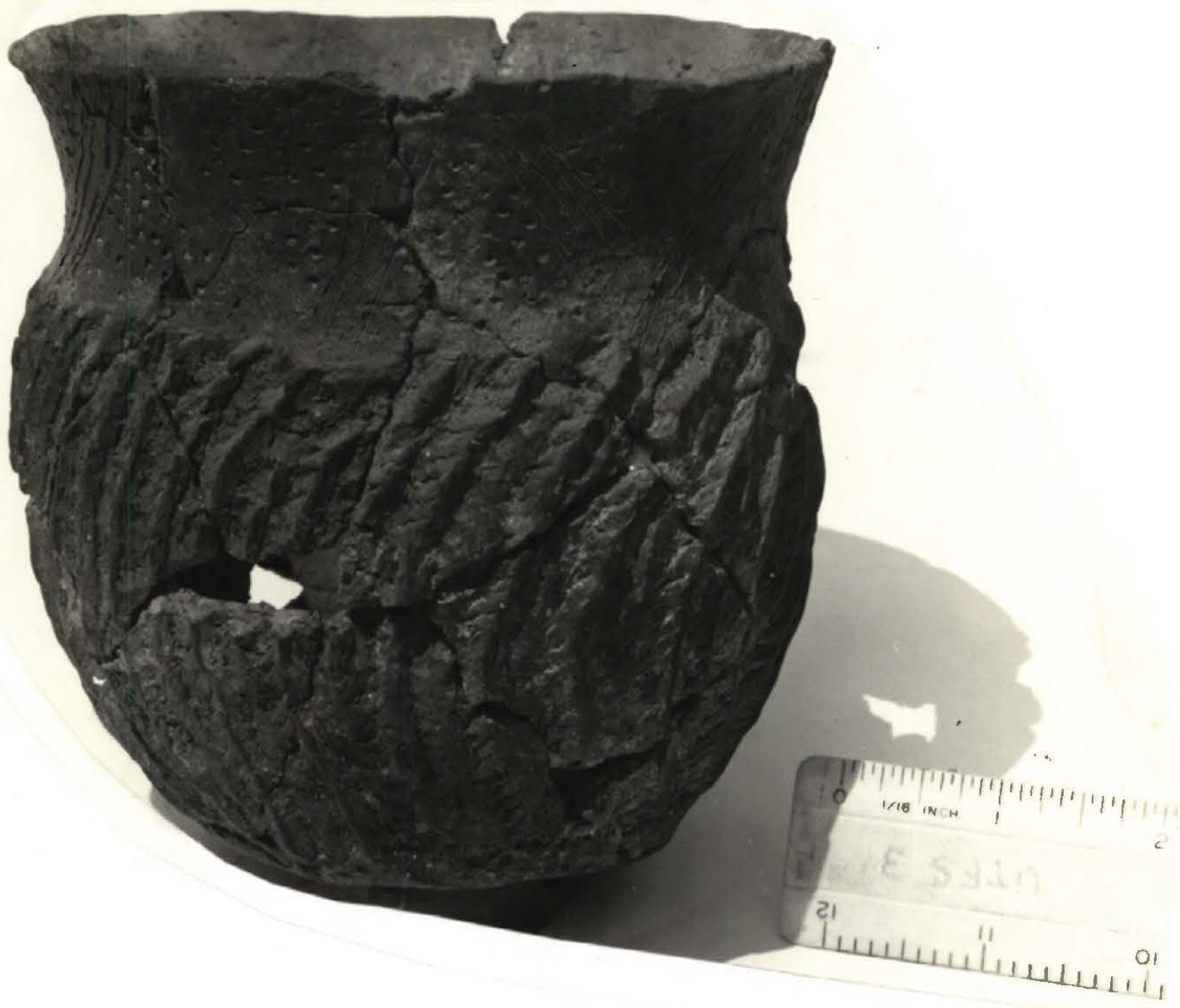

Figure 18. Incised-Punctated and pinched jar from Burial 2 (Vessel 3). 


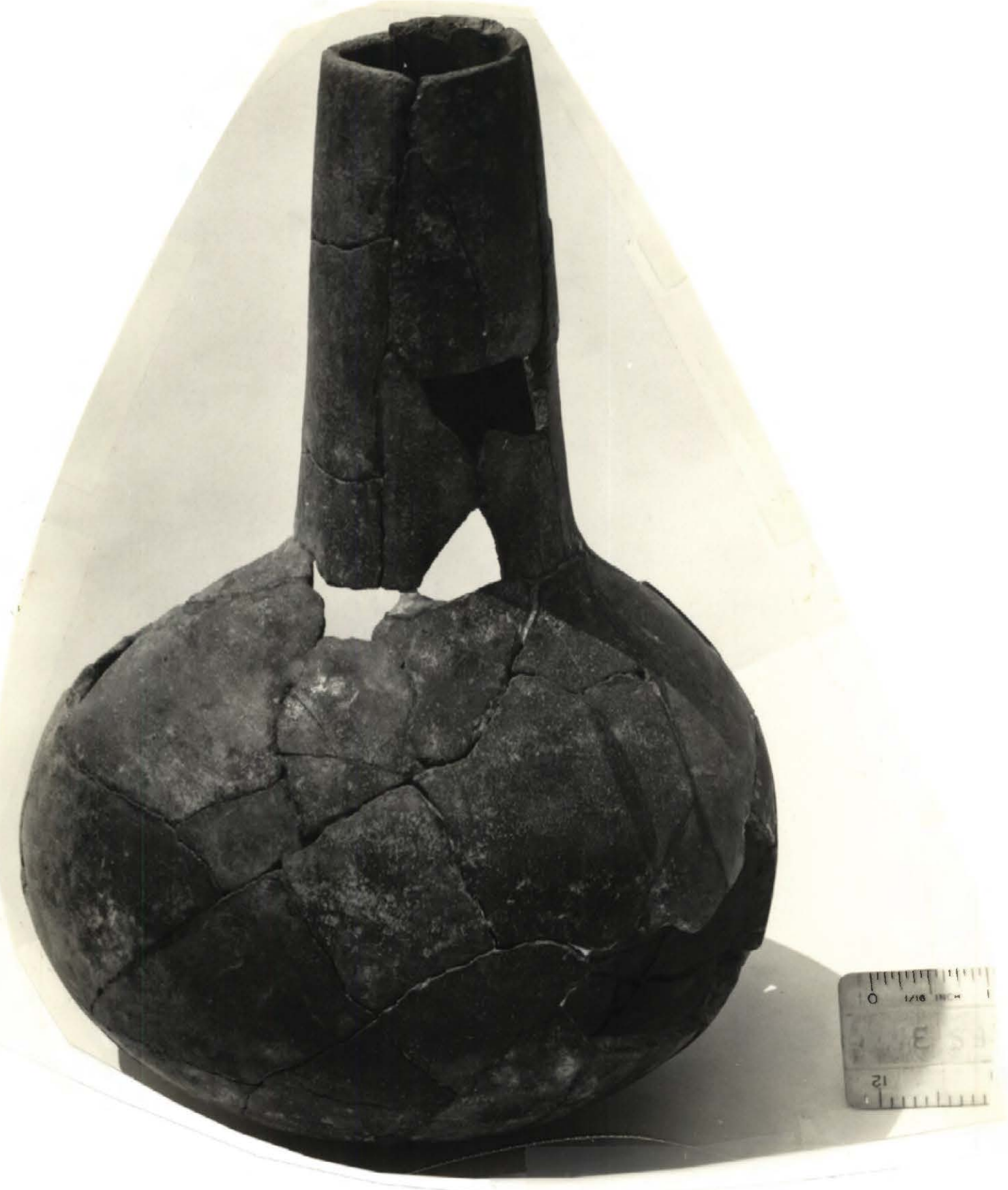

Figure 19. Vessel 5, Burial 2. 


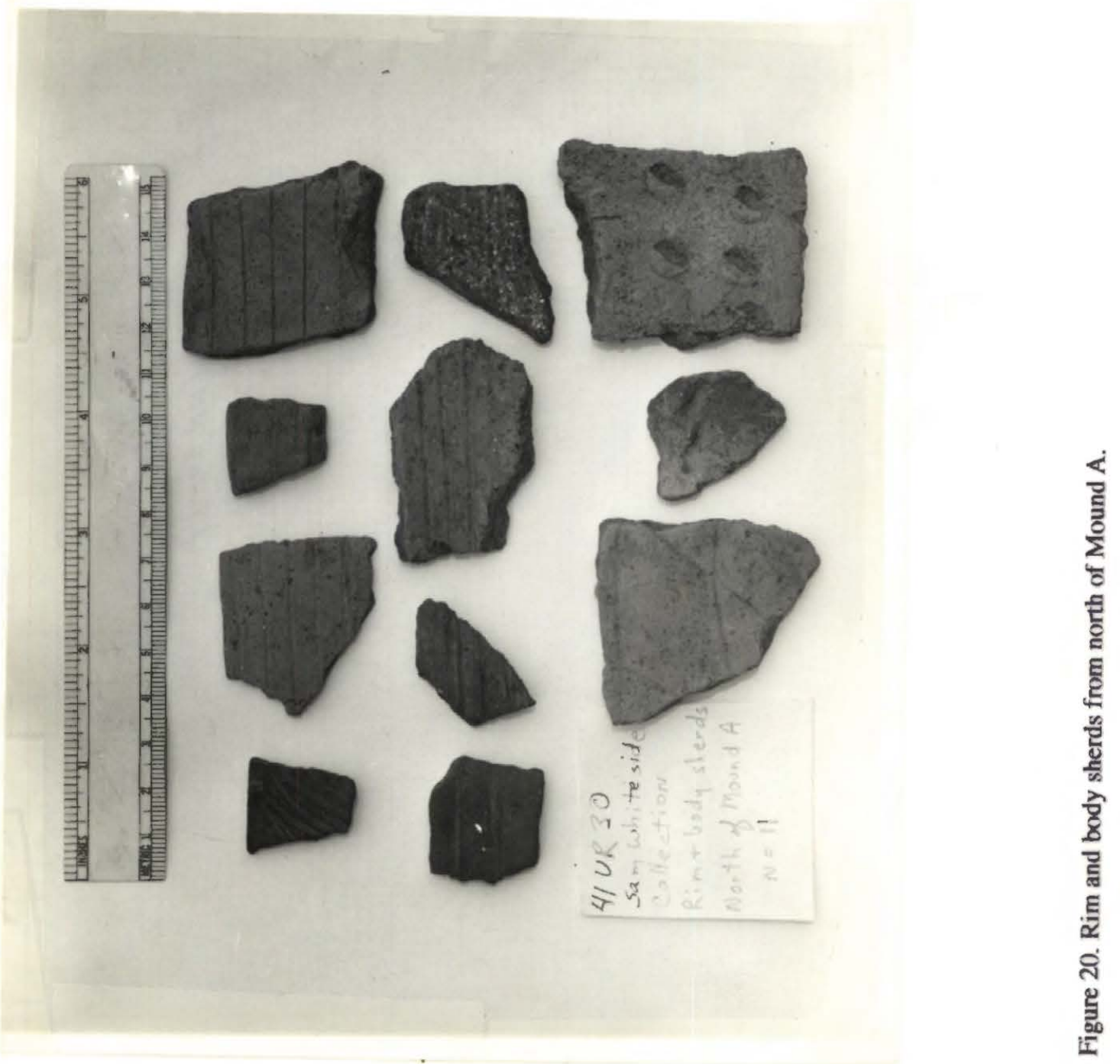




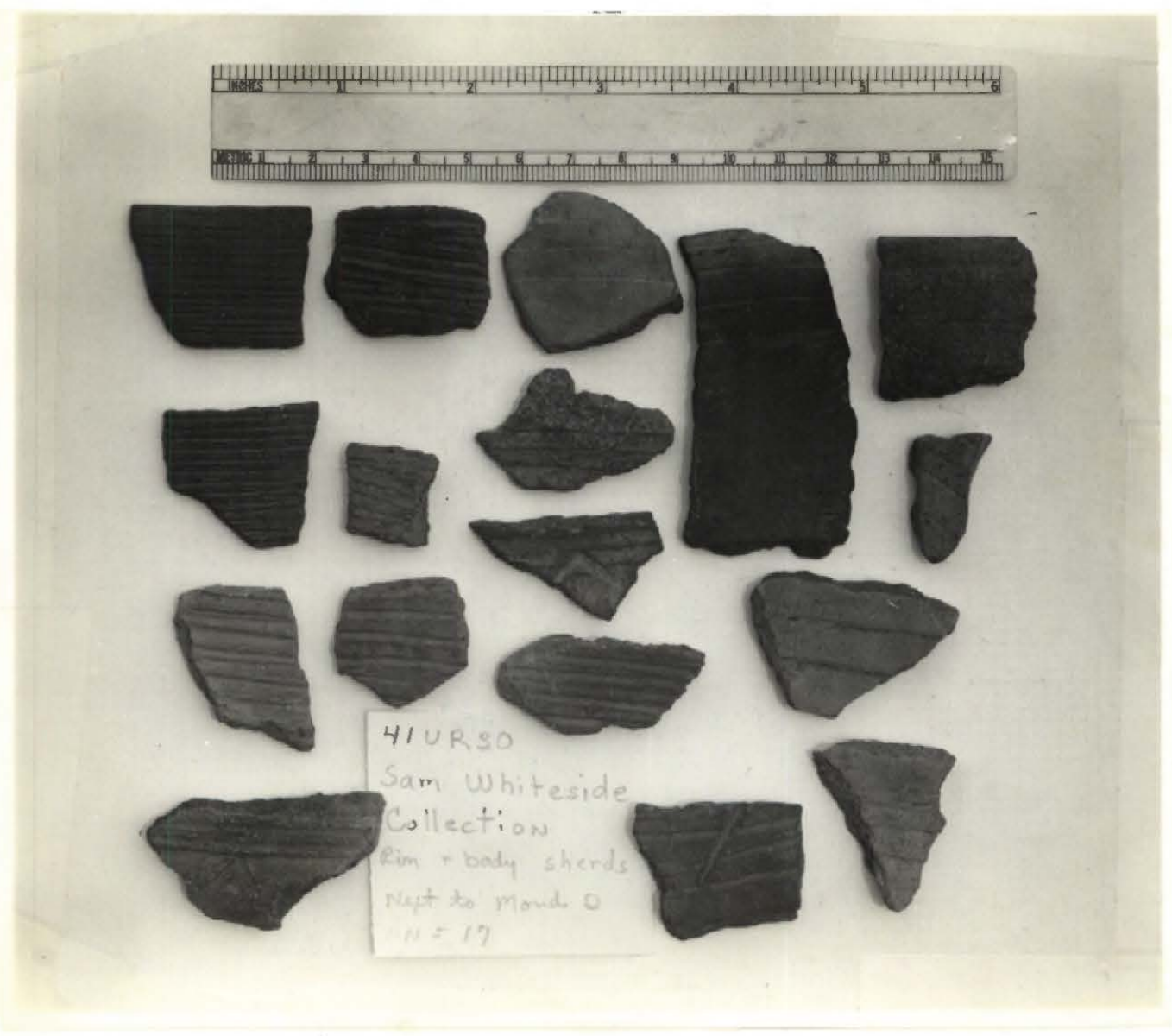

Figure 21. Rim and body sherds next to Mound D. 


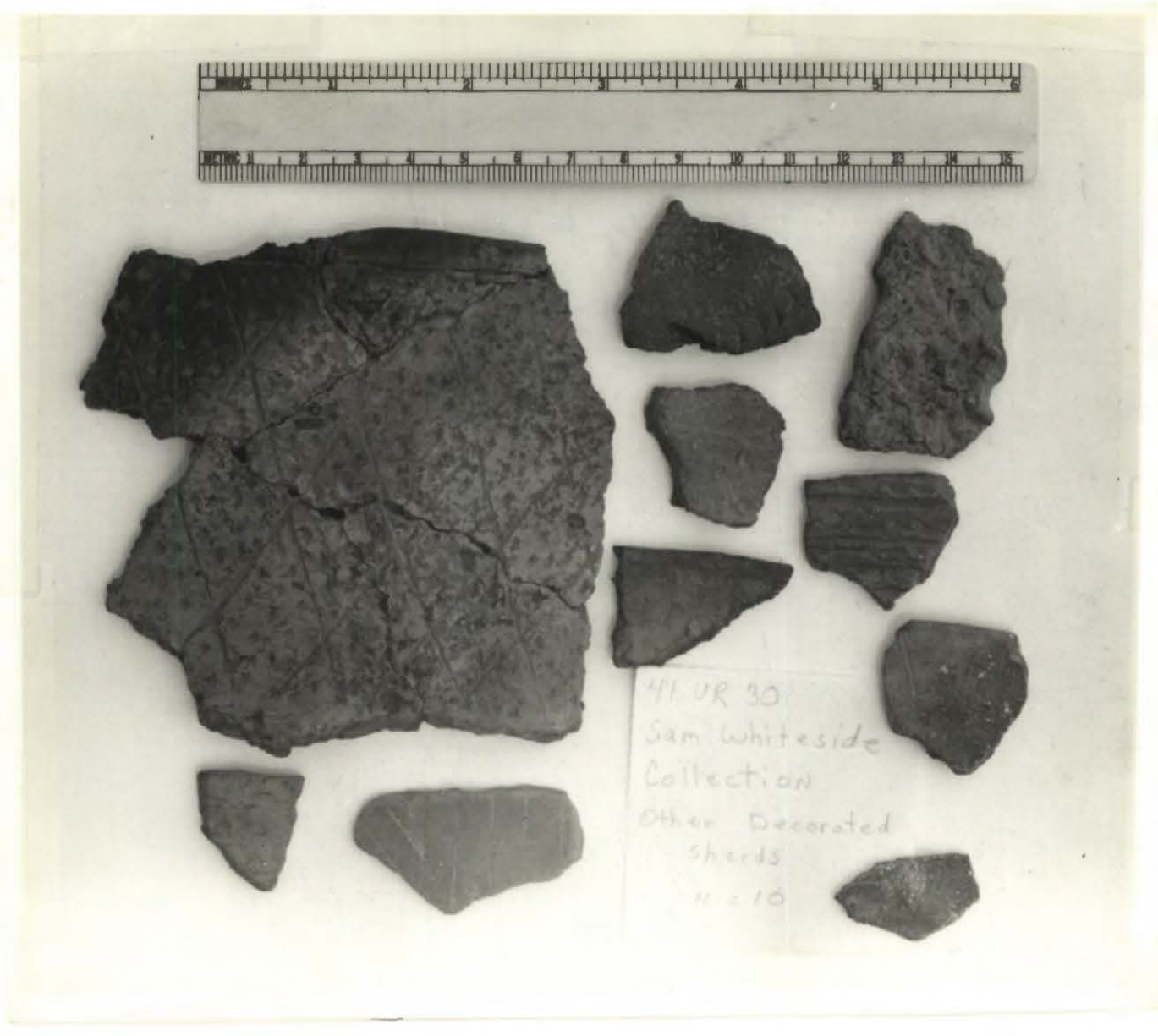

Figure 22. Decorated sherds from general contexts. 
Walters also retains a small collection of materials from Mound $\mathrm{A}$ and from general contexts. This general collection includes the following items: six unmodified pebbles, one tested cobble, six cores and core fragments, 18 pieces of lithic debris, one bifacial tool fragment, three pieces of burned clay, one parallel brushed ceramic body sherd, onc Coles Creek Incised, var. Coles Creek body sherd (see Phillips 1970), two plain rims, and 87 plain body sherds. The lithic artifacts are on local quartzites, petrified wood, and cherts. About 18 percent of the ceramics are bone-tempered, including the one brushed body sherd.

From Mound A, and probably from Burial 1, are nine lithic artifacts; the association is not clear because Whiteside's notes do not indicate that other stone tools were found in association with Burial 1 besides a celt (see Figure 6) and a mano (see Figure 11). Among them is a small quartzite polishing stone, two large bifacial tool fragments (probably from Gahagan-style bifaces), and six Alba or Homan arrow points. The bifacial tool fragments are made from gray and dark gray cherts that are not locally available; one specimen has well-ground tool edges. Four of the six arrow points are made on local red chert and coarse-grained quartzite, and they have expanding stems with convex rounded bases. The other two arrow points are made of a black chert (Big Fork chert) that originates in the Ouachita Mountains (see Banks 1990). They also have expanding stems with convex rounded bases and squared shoulders; one has been broken by an impact fracture.

Of unknown provenience--but probably from Mound A investigations--are 14 sherds from the plain body of a small, thin $(4.9 \mathrm{~mm})$, and well-made bottle. The sherds have a burnished exterior.

\section{Dee Ann Story Investigations}

Dee Ann Story, then of TARL, visited the Boxed Springs site in about 1982 and made a quick plan map of the sitc (Figure 23). On it, she noted four evenly-spaced mounds (labeled Mounds A-D) around a central open area, probably a plaza, with several areas of midden deposits to the north of Mound A, north, south, and west of Mound B, northeast of Mound C, and between Mounds C and D (see also Figure 3). There was also evidence of pothunting digging activities south and southeast of Mound $C$, near the bluff edge overlooking the Sabine River. Her map also includes a mctal farm building to the north of the mound and plaza area (see Figure 23), and the farm building is situated on a large knoll near the apparent northern end of the associated Early Caddoan village.

\section{Sabine River Mound Sites Study}

The senior author of this section first inspected the Boxed Springs site during the course of the archacological survey investigations in the proposed Texas Big Sandy project on Big Sandy Creek in Wood and Upshur counties, Texas (Perttula et al. 1986). He also had an opportunity to visit with $\mathrm{Mr}$. Whiteside and examine the collections and available notes from the site.

In 1988, he returned to the site to document it as part of a larger study of mound sites along the Sabine River in Northeast Texas and Northwest Louisiana (Perttula 1989, 1994). At the time, the site was in an overgrazed pasture, with well-worn cattle trails and bare patches across the area. Archaeological materials were noted on the surface west of Mound A and in a midden deposit at the south end of the landform between Mounds C and D (see Figure 23). Pothunting activities were noted south of Mound $C$, and this work had apparently found numerous ceramic sherds but no obvious features. The landowner also informed us 

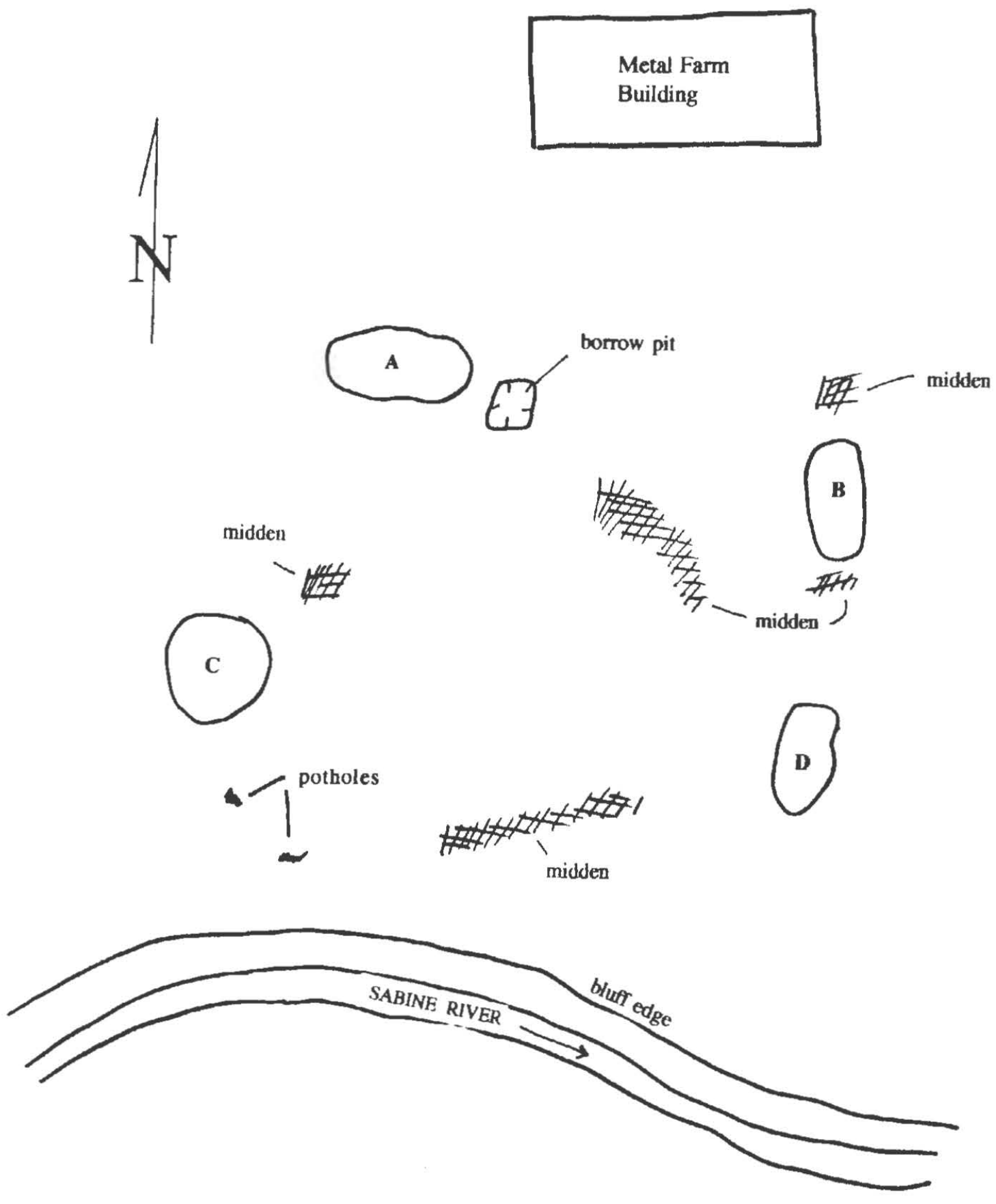

Figure 23. Dee Ann Story map of Boxed Springs site, ca. 1982. 
that a large novaculite bifacial tool had been found east of Mound D during the excavation of a septic tank.

A small amount of artifacts were collected from a surface collection west of Mound A and between Mounds $\mathrm{C}$ and $\mathrm{D}$. In the first collection was a fragment of a large bifacial tool of gray chert (probably of non-local origin), two core fragments of Ogallala quartzite and tan chert, and two grog-grit-tempered plain body sherds; one of these thin $(4.2 \mathrm{~mm})$ sherds had been burnished on its exterior surface.

The second surface collection between Mounds C and D had 12 pieces of lithic debris and five ceramic sherds. The lithic raw materials represented among the debris included ferruginous sandstone, yellow chert, red chert, Ogallala quartzite, gray chert, novaculite, and jasper. The novaculite and jasper, and probably the gray chert, are definitely from nonlocal raw material sources (i.e., Red River gravels in northeastern Texas). One of the sherds has fine line horizontal engraving, and it was tempered with finely crushed grog. Two other sherds are flat bases (11-12 mm in thickness) tempered with grog-grit-bone inclusions. The remaining sherds included a $6.5 \mathrm{~mm}$ thick grog-tempered plain body sherd and a $5.5 \mathrm{~mm}$ thick grog-grit-bone-tempered sherd from a plain bottle.

A single shovel test was excavated in the midden deposits between Mounds $\mathrm{C}$ and $\mathrm{D}$, and nine artifacts were recovered. These included five pieces of lithic debris, all of local petrified wood, tan chert, and quartzite), an Alba arrowpoint of Ogallala quartzite, and three grog-tempered ceramic sherds. Two of the sherds are plain, while the third has a small fingernail punctated decorative element.

\section{Documentation of the Red McFarland Collection from the Boxed Springs Site}

Red McFarland, from Whitehouse, Texas, dug approximately 150 burials at the Boxed Springs site in 1990 . These burials were in a single large cemetery at the northern end of the site, away from the mounds, and the burials were reported to be almost exclusively single, extended, supine burials, with the notable exception of the one cremation reported on here by Wilson.

Very little information is available on any of the burials, either their orientation, depth, or condition of the human remains, and associational data are also sparse. The associational information will be summarized below in the discussion of the funerary objects documented from the Boxed Springs site. The original photographs and documentation notes are on file at the Archeology Division, Texas Historical Commission. It is our understanding that much of the Boxed Springs collection has been sold since it was documented in 1990.

A total of 78 lithic artifacts are in the collection, including large chipped bifaces, dart points, numerous arrow points, a scraper, celts, and a bipolar core. The three large bifaces are Gahagan bifaces; two are chipped from Central Texas chert, and the third is on an unidentified non-local chert. One of the large bifaces occurred in burial association with a plain bowl.

There are three large dart points or knives, all three with contracting stems; one of the tools has been extensively resharpened or reworked, and may have seen use as a knive. This tool is on novaculite, a non-local raw material. One of the other dart points is on a non-local raw material (Red River chert), and the third is from a local raw material. 
The bipolar core is on a local chert, probably a small pebble available in upland gravels in the Sabine River basin. The single bifacial scraper is on a tabular piece of locally available petrified wood.

There are five groundstone cclts in the McFarland collection. One is on a quartzitic sandstone from the Ouachita Mountains, and a second is on chert; the three others appear to be on locally available hematite.

McFarland found 65 arrow points in the cemetery. In one burial, the arrow points included Alba, Alba or Catahoula, and Agee types. The arrow points include seven Alba or Catahoula, 40 Alba, eight Homan, two Friley, one Steiner, two Agee, one corner-notched (Scallorn?), three contracting stem forms, and one unidentifiable fragment. The arrow points are predominately manufactured from locally available chert and quartzite raw materials (Table 1). Only 4.6 percent of the arrow points are on non-local lithics (see Table 1), and these (Ouachita Mountains cherts and siltstone) appear to be from Red River gravel sources (see Banks 1990).

Table 1. Raw Materials among the Arrow Point Types

\begin{tabular}{|c|c|c|c|c|c|c|}
\hline Type & Local & Non-Local & Chalcedony & $\begin{array}{l}\text { Petrified } \\
\text { Wood }\end{array}$ & Siltstone & $\begin{array}{l}\text { Ouachita } \\
\text { Mtns. }\end{array}$ \\
\hline Alba or & & & & & & \\
\hline Catahoula & 7 & - & - & - & - & - \\
\hline Alba & 37 & - & 1 & 1 & 1 & - \\
\hline Homan & 7 & - & - & - & - & 1 \\
\hline Friley & 2 & - & - & - & - & - \\
\hline Agee & 1 & 1 & - & - & - & - \\
\hline Steiner & 1 & - & - & - & - & - \\
\hline $\begin{array}{l}\text { Comer- } \\
\text { notched }\end{array}$ & 1 & - & - & - & - & - \\
\hline $\begin{array}{l}\text { Contracting } \\
\text { stem }\end{array}$ & 3 & - & - & - & - & - \\
\hline UID frag. & 1 & - & - & - & - & - \\
\hline
\end{tabular}

Two of the burials apparently had copper-covered shell earspools, two earspools per burial (for a total of four shell carspools), but other associational information is not available. There are a number of copper-covered earspools at the George C. Davis site from F118, F119, F155, and F161, representing shaft tomb interments from Stage I-IV in Mound C. Copper plated ear ornaments have been reported at Mounds Plantation (Wcbb and McKinney 1975:103-104 and Figure 14), but in both Gcorge C. Davis and Mounds Plantation contexts, the copper covered either stone or wood, not shell. 
Vessels, vessel sections, sherds, a long-stemmed Red River pipe, and clay earspools comprise the ceramic artifacts in this Boxed Springs collection. As previously mentioned, the one long-stemmed Red River pipe was apparently found in association with Fast Incised and Spiro Engraved vessels. The six clay earspools were found in six different burials, one earspool per burial, and one of these burials had a Crenshaw Fluted jar (cf. Durham and Davis 1975:36 and Figure 19) and an incised jar. In another case, a plain carinated bowl and a dish were noted to have been found together in a burial, and in a final example, one burial had six vessels placed with it, including a Hickory Engraved bottle, a plain bowl with a peaked rim, a plain bottle, a plain jar, a horizontally incised jar, and a small tray.

Table 2 lists the 160 ceramic vessels/vessel sections and 23 sherds in this Boxed Springs collection. Plain vessels include 36 percent of the 160 vessels, engraved finewares comprise 44 percent of the vessels, and the incised, punctated, punctated-incised, and pinched wares represent the remaining 20 percent of the assemblage (see Table 2).

\section{Table 2. Ceramic Vessels, Vessel Sections, and Sherds}

\begin{tabular}{|c|c|c|}
\hline Ceramic Category & Vessel/Vessel Section & Sherds \\
\hline Hickory Engraved & 32 & 5 \\
\hline Spiro Engraved & 14 & 2 \\
\hline Holly Fine Engraved & 12 & \\
\hline Unidentified Engraved & 9 & 2 \\
\hline Holly-Spiro Engraved & 3 & 2 \\
\hline Unidentified Horizontal Engraved & 1 & \\
\hline Subtotal, Engraved & 71 & 11 \\
\hline Plain bottles & 29 & \\
\hline Plain bowls and carinated bowls & 27 & 2 \\
\hline Plain jar & 1 & \\
\hline Subtotal, Plain & 57 & 2 \\
\hline Horizontal Incised & 9 & 5 \\
\hline Coles Creek Incised & 5 & 1 \\
\hline Weches Fingemail Impressed & 3 & \\
\hline Kiam Incised & 2 & \\
\hline East Incised & 2 & \\
\hline Unidentified Incised-Punctated & 2 & \\
\hline Punctated & 2 & 1 \\
\hline Pinched-Punctated & 1 & 1 \\
\hline Crockett Curvilinear-Incised & 1 & \\
\hline Crenshaw Fluted & 1 & \\
\hline Horizontal-Vertical Incised & 1 & \\
\hline Incised-Pinched & 1 & \\
\hline Zoned Incised-Punctated & 1 & \\
\hline Fingernail Punctated & 1 & \\
\hline Parallel Incised & & 1 \\
\hline Punctated-Appliqued & & 1 \\
\hline $\begin{array}{c}\text { Subtotal, Decorated } \\
\text { Utility Wares }\end{array}$ & 32 & 10 \\
\hline
\end{tabular}


By comparison, 80 percent of the five vessels in Early Caddoan burial pits at the Mounds Plantation site were engraved (three Holly Fine Engraved and one Hickory Engraved), and the other vessel was an elaborate Crockett-Pennington hybrid (Webb and McKinney 1975). At the George C. Davis site, 100 percent of the 10 vessels found in Mound C burial pits were engraved (Story 1997). Clearly engraved vessels were particularly important ceramic funerary objects in Early Caddoan burial pits in northwestern Louisiana and East Texas.

Early Caddoan burial pits (pits D-F, I-K, M, N, Q, and R) in Mound C at the Crenshaw site (Durham and Davis 1975), on the other hand, had a much lower proportion of engraved wares among the ceramic funerary offerings (46 percent, mainly Spiro Engraved, Hickory Engraved, and Holly Fine Engraved), and a correspondingly higher percentage of plain (16 percent) and incised, incised-punctated, punctated, and pinched (27 percent) vessels, much like the vessel assemblage in the Boxed Springs non-mound cemetery. The most significant difference between the Mound $\mathrm{C}$ vessel assemblage at Crenshaw and the Boxed Springs assemblage is the high proportion of plain bottles and bowls at Boxed Springs (see Table 2).

However, Early Caddoan village area pottery at the George C. Davis site is not dominated by engraved sherds. In a large sample described by Stokes and Woodring (1981), engraved sherds represent about 26 percent of several thousand decorated sherds, with the remainder of the decorated sherds comprised of incised, incised-punctated, fingernail impressed, pinched, and neck banded specimens. Thus, engraved vessels were used, broken, and discarded in village contexts during Early Caddoan times at this mound center, but the village assemblage is dominated by utility ware jars and bowls. The Boxed Springs vessel assemblage from the non-mound cemetery is also composed of many utility ware jars and bowls, suggesting it was derived from residential or every-day use at the site.

Figures 24-28 are selected examples of a number of the decorated jars, bowls, and bottles found in the non-mound cemetery at the Boxed Springs site. The decorated utility ware jars and deep bowls from Boxed Springs include a number of vessels with a series of horizontal incised lines on the rim, other examples with horizontal incised decorations on the rim and vertical incised lines on the body (see Figure 27c and Figure 28a), or with punctated bodies and incised rims (see Figure 24a). There are also distinctive Coles Creek Incised vessels with horizontal incised lines on the rim and triangular impressions/punctations at the rim/body juncture (see Figure 24b-c and Figure 27f), a Kiam Incised bowl with multiple incised lines on the rim and fingernail punctations on the body (see Figure 27i), and Weches Fingernail Impressed jars and bowls with punctated bodies and rims (see Figure $24 \mathrm{f}$ and Figure 26e). A punctated rim jar and a pinchedpunctated jar are also present in the collection (see Figure $24 \mathrm{~d}-\mathrm{e}$ ). One incised-punctated bowl has rim peaks and a design of multiple horizontal incised lines with small punctations between the incised lines (see Figure 27e).

The decorated bottles are dominated by horizontal engraved bodies and necks from small and large Hickory Engraved specimens (see Figure 25a-b, d). One Hickory Engraved bottle has multiple curvilinear and concentric engraved lines on the globular body (see Figure 25e), and an unidentified engraved bottle has four horizontal engraved lines below the bottle neck, with sets of semi-circular engraved lines pendant from the lowermost horizontal engraved line (see Figure 25c).

The plain and decorated bowls (primarily with engraved decorations of Spiro Engraved, Holly Fine Engraved, and Hickory Engraved) from the non-mound cemetery have a diversity of forms, including simple bowls with straight walls and direct rims (see Figure $26 \mathrm{e}$, Figure 27b, and Figure 28b), carinated bowls (see Figure 26a), bowls with inverted rims (see Figure 26c, e), beakers (see Figure 26g-i), barrel-shaped forms (see Figure 27a, 

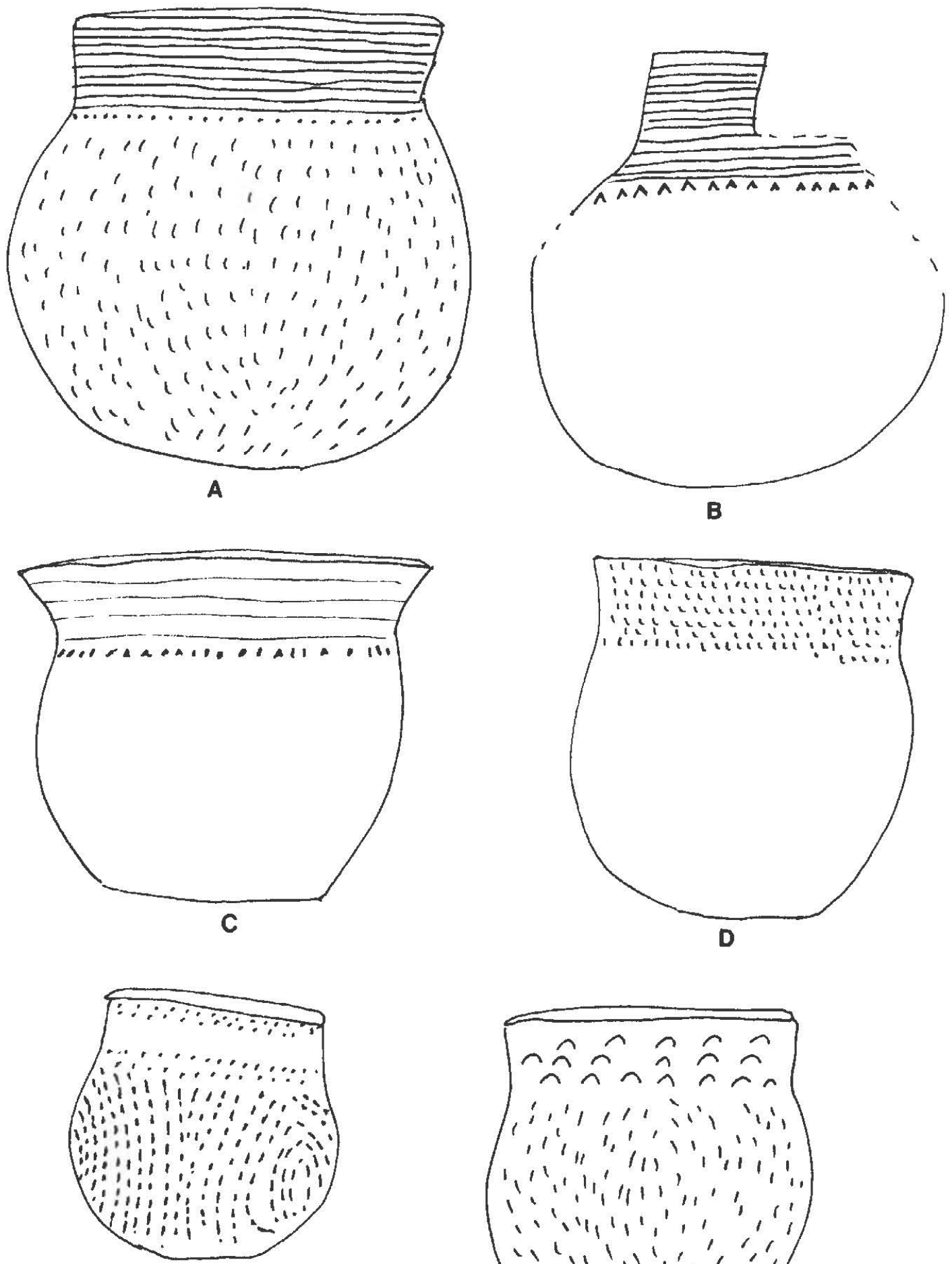

$\mathbf{E}$

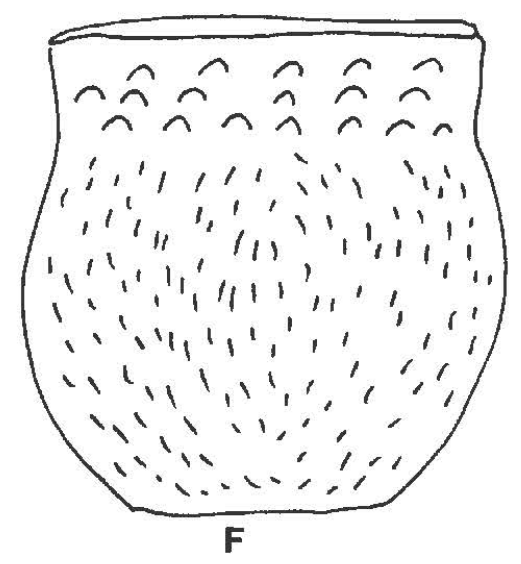

Figure 24. Decorated jars from cemelery: a, Kiam Incised; b-c, Coles Creek Incised; d, punctated jar; e, punctaled and pinched; $f$, Weches Fingernail Impressed. Vessel a is $22.3 \mathrm{~cm}$ in height. 


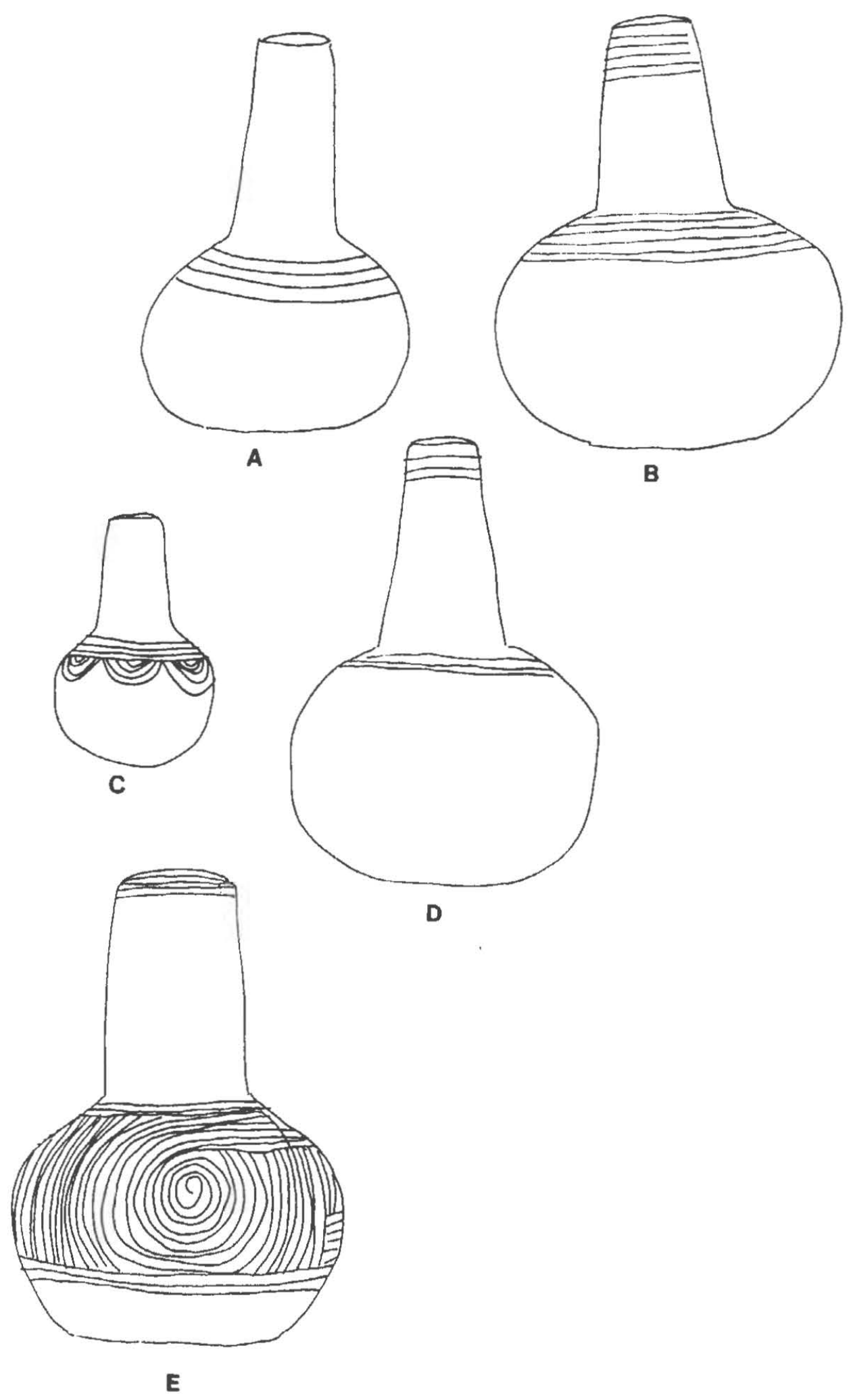

Figure 25. Decorated botlles from cemetery: a, b, d, Hickory Engraved; c, horizontal and semi-circular engraved; e, horizontal, vertical, and concentric circle engraved. Vessel $b$ is $25.4 \mathrm{~cm}$ in height. 


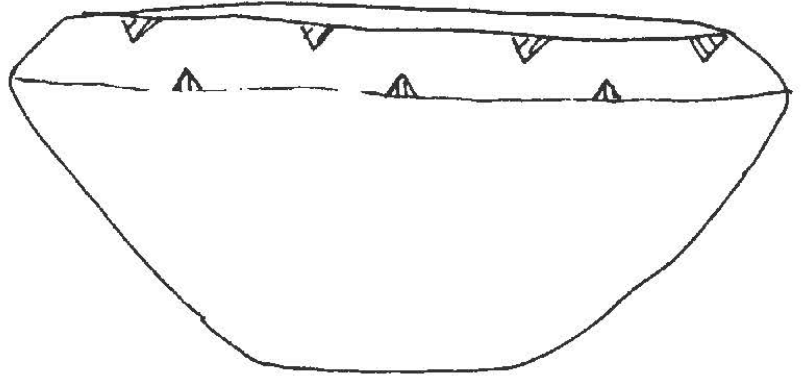

A

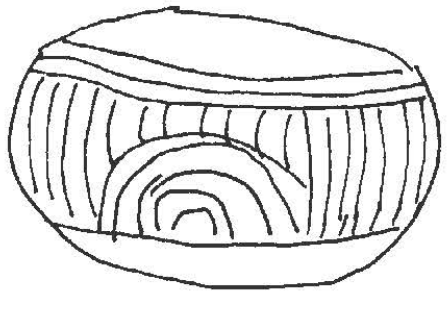

C

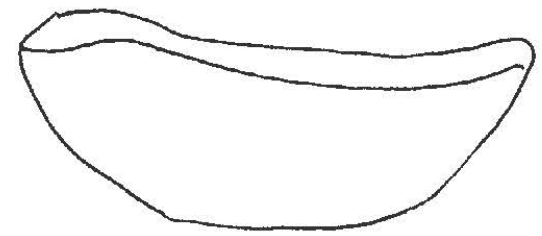

B

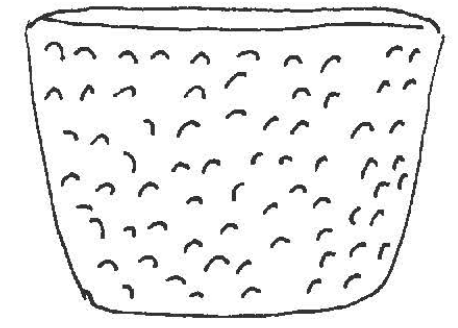

E

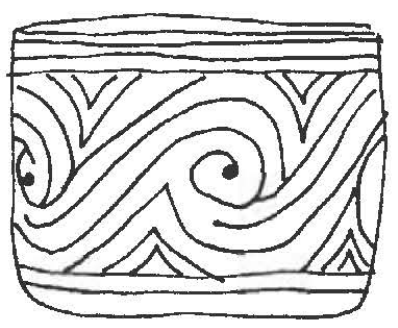

G
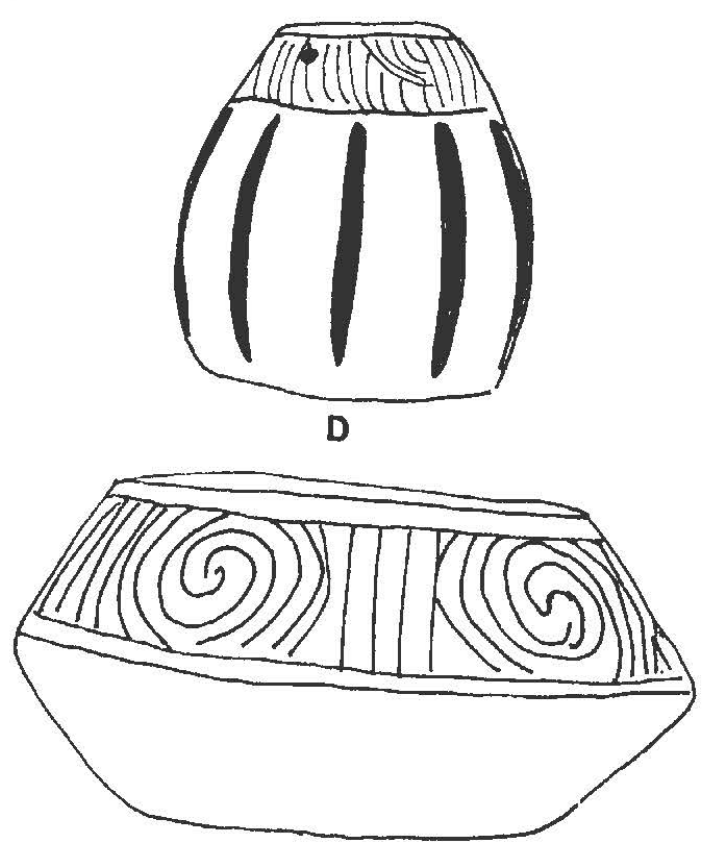

$\mathbf{F}$
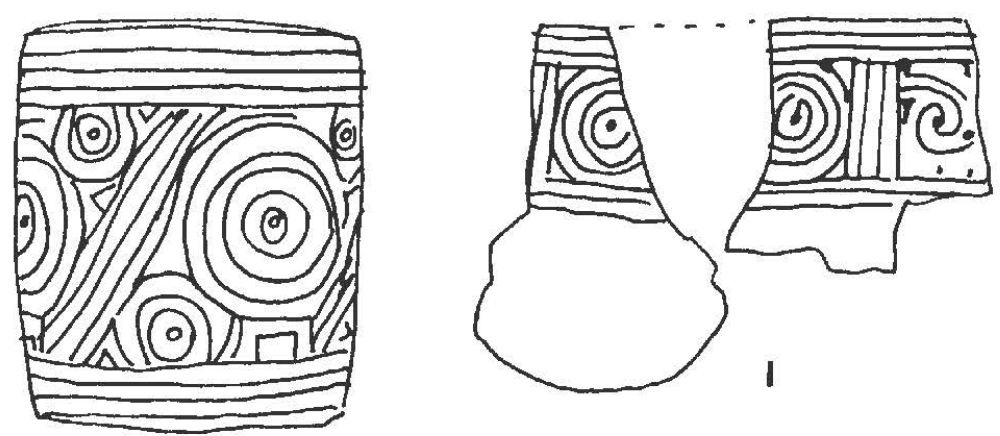

H

Figure 26. Decorated bowls and beakers from cemetery: a, pendant triangles; b, peaked rim bowl; c, Spiro Engraved (?); d, Spiro Engraved with flutes; e, Weches Fingernail Impressed; f, Holly Finc Engraved; g-i, Spiro Engraved. Vessel a is $11.2 \mathrm{~cm}$ in height. 


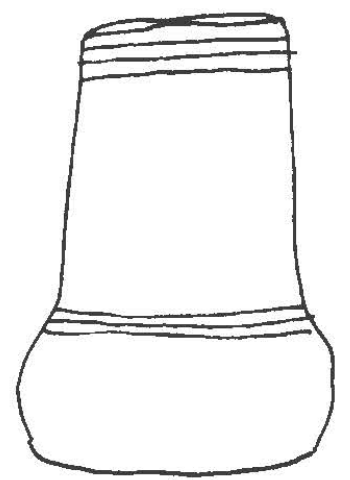

A

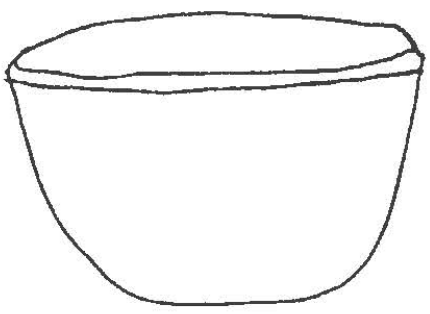

B

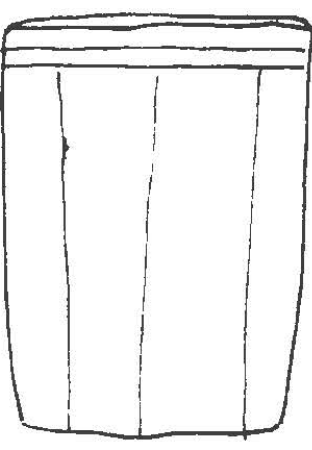

$\dot{c}$

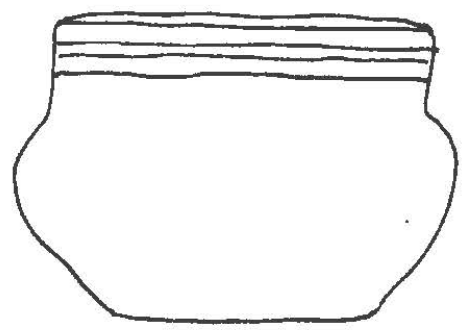

D

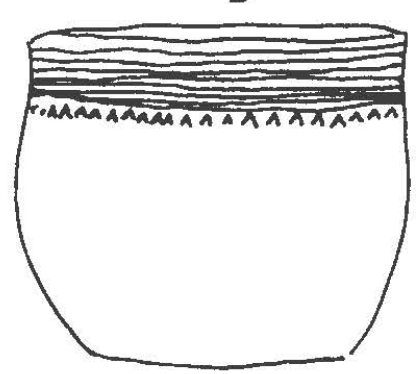

$\mathbf{F}$

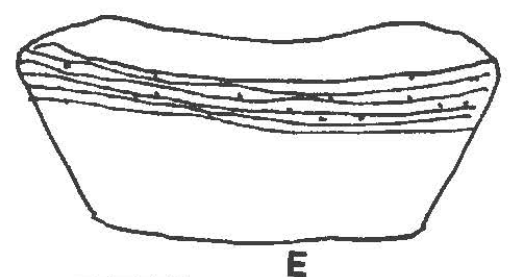

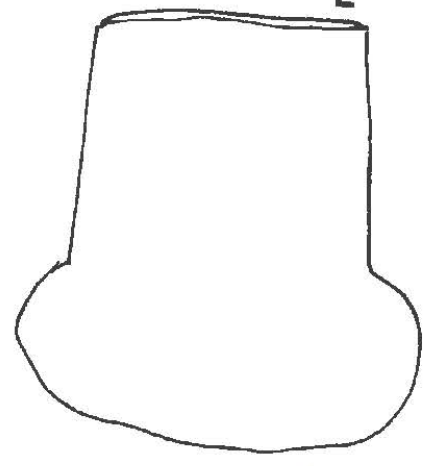

G

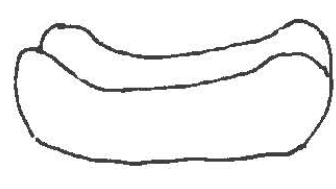

H
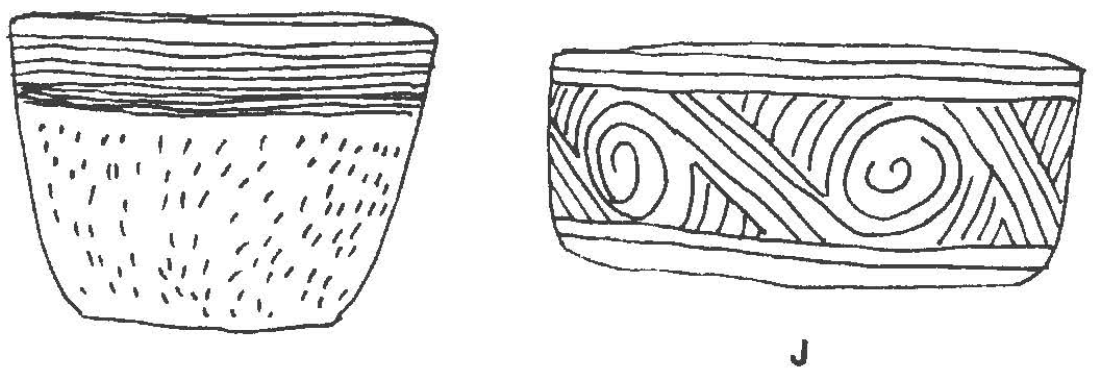

I

Figure 27. Plain and decorated bowls and other vessel forms from cemetery: a, b, d, Hickory Engraved; c, Horizontal and vertical incised jar; e, Incised-punctated, rim peaks; f, Coles Creek Incised; g, plain barrel-shaped; h, 4-peaked bowl; i, Kiam Incised; Spiro Engraved. Vessels a-c at same scale, Vessel A is $18.5 \mathrm{~cm}$ in height; Vesseis $d-j$ at same scale, Vessel $D$ is $10.2 \mathrm{~cm}$ in height. 

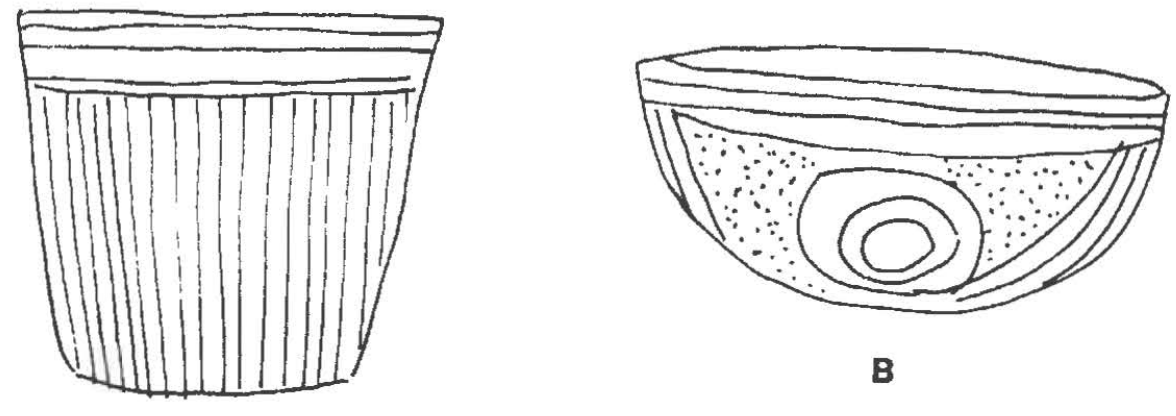

A

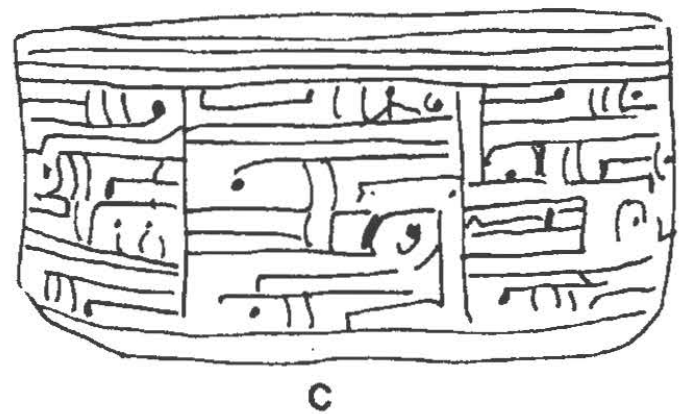

Higure 28. Decorated vessels from cemetery: a, Incised jar; b, Crockett Curvilinear Incised; c, unidentified engraved carinated bowl. Vessel a is $12.2 \mathrm{~cm}$ in height. 
g), globular bowls (see Figure 27d), peaked bowls (see Figure 26b and Figure 27h), and shallow but wide bowls (see Figure $27 \mathrm{j}$ and Figure 28c). One form resembles a gourd or seed jar (see Figure 26d), and it has an engraved motif along the rim, and deep vertical flutes on the body, resembling Crenshaw Fluted forms; another fluted form from Boxed Springs has a Spiro Engraved motif with fluted channels cut through the engraved motif.

One of the carinated bowls has a series of large engraved pendant triangles (see Figure 26a) along the rim, reminiscent of engraved motifs more commonly seen in Middle Caddoan contexts in the upper and middle reaches of the Sabine River basin. Another, probably a Crockett Curvilinear Incised vessel, has horizontal incised lines on the rim, and vertical and concentric circles on the body between panels filled with small punctations (see Figure $28 \mathrm{~b}$ ). One of the shallow but wide bowls has a unique engraved motif of horizontal lines on the rim and a series of panels filled with short interlocking scrolls and small excised circles or dots (see Figure 28c).

\section{REFERENCES CITED}

Banks, L. D.

1990 From Mountain Peaks to Alligator Stomachs: A Review of Lithic Sources in the Trans-Mississippi South, the Southern Plains, and Adjacent Southwest. Memoir No. 4. Oklahoma Anthropological Society, Norman.

Buikstra, J. and D. Ubclaker (editors)

1994 Standards for DataCollection from Human Skeletal Remains. Research Series No. 44. Arkansas Archeological Survey, Fayetteville.

Durham, J. H. and M. K. Davis

1975 Report on Burials found at Crenshaw Mound "C," Miller County, Arkansas. Bulletin of the Oklahoma Anthropological Society 23:1-90.

Perttula, 'T. K.

1989 A Study of Mound Sites in the Sabine River Basin, Northeast Texas and Northwest Louisiana. Institutc of Applied Sciences, University of North Texas, Denton.

1994 Mound Sites in the Sabine River Basin of Northeast Texas. Caddoan Archeology Newsletter IV(4):4-19.

Perttula, T. K. (editor)

1999 The Hurricane Hill Site (41HPIO6): The Archeology of a Late Archaic/Early Ceramic and Early-Middle Caddoan Settlement in Northeast Texas. 2 Vols. Special Publication No. 4. Friends of Northeast Texas Archaeology, Pittsburg and Austin.

Perttula, T. K., B. D. Skiles, M. B. Collins, M. C. Trachte, and F. Valdez, Jr.

1986 "This Everlasting Sand Bed": Cultural Resources Investigations at the Texas Big Sandy Project, Wood and Upshur Counties, Texas. Reports of Investigations No. 52. Prewitt and Associates, Inc., Austin.

Phillips, P.

1970 Archaeological Survey in the Lower Yazoo Basin, Mississippi, 1949-1955. 2 Vols. Papers of the Peabody Museum of Archaeology and Ethnology, Vol. 60. Peabody Museum of Archaeology and Ethnology, Harvard University, Cambridge. 
Roberts, K.

1983 Soil Survey of Upshur and Gregg Counties, Texas. United States Department of Agriculture, Soil Conservation Service, in cooperation with the Texas Agricultural Experiment Station.

Shafer, H. J.

1973 Lithic Technology at the George C. Davis Site, Cherokee County, Texas. Ph.D. dissertation, Department of Anthropology, The University of Texas at Austin.

Steele, D. G.

1976 The Estimation of Sex on the Basis of the Talus and Calcaneus. American Journal of Physical Anthropology 45:581-588.

Stokes, J. and J. Woodring

1981 Native-made Artifacts of Clay. In Archeological Investigations at the George C. Davis Site, Cherokee County, Texas: Summers of 1979 and 1980, edited by D. A. Story, pp. 135-238. Occasional Papers, No. 1. Texas Archeological Research Laboratory, The University of Texas at Austin.

Story, D. A.

1997 1968-1970 Archeological Investigations at the George C. Davis Site, Cherokee County, Texas. Bulletin of the Texas Archeological Society 68:1-113.

Webb, C. H. and R. R. McKinney

1975 Mounds Plantation (16CD12), Caddo Parish, Louisiana. Louisiana Archaeology 2:39-127. 